\title{
Parenchymal neuroinflammatory signaling and dural neurogenic inflammation in migraine
}

\author{
Şefik Evren Erdener ${ }^{1}$, Zeynep Kaya ${ }^{1}$ and Turgay Dalkara ${ }^{2^{*}}$ (D)
}

\begin{abstract}
Background: Pain is generally concomitant with an inflammatory reaction at the site where the nociceptive fibers are activated. Rodent studies suggest that a sterile meningeal inflammatory signaling cascade may play a role in migraine headache as well. Experimental studies also suggest that a parenchymal inflammatory signaling cascade may report the non-homeostatic conditions in brain to the meninges to induce headache. However, how these signaling mechanisms function in patients is unclear and debated. Our aim is to discuss the role of inflammatory signaling in migraine pathophysiology in light of recent developments.
\end{abstract}

Body: Rodent studies suggest that a sterile meningeal inflammatory reaction can be initiated by release of peptides from active trigeminocervical C-fibers and stimulation of resident macrophages and dendritic/mast cells. This inflammatory reaction might be needed for sustained stimulation and sensitization of meningeal nociceptors after initial activation along with ganglionic and central mechanisms. Most migraines likely have cerebral origin as suggested by prodromal neurologic symptoms. Based on rodent studies, a parenchymal inflammatory signaling cascade has been proposed as a potential mechanism linking cortical spreading depolarization (CSD) to meningeal nociception. A recent PET/MRI study using a sensitive inflammation marker showed the presence of meningeal inflammatory activity in migraine with aura patients over the occipital cortex generating the visual aura. These studies also suggest the presence of a parenchymal inflammatory activity, supporting the experimental findings. In rodents, parenchymal inflammatory signaling has also been shown to be activated by migraine triggers such as sleep deprivation without requiring a CSD because of the resultant transcriptional changes, predisposing to inadequate synaptic energy supply during intense excitatory transmission. Thus, it may be hypothesized that neuronal stress created by either CSD or synaptic activity-energy mismatch could both initiate a parenchymal inflammatory signaling cascade, propagating to the meninges, where it is converted to a lasting headache with or without aura.

Conclusion: Experimental studies in animals and emerging imaging findings from patients warrant further research to gain deeper insight to the complex role of inflammatory signaling in headache generation in migraine.

\footnotetext{
* Correspondence: tdalkara@hacettepe.edu.tr

${ }^{2}$ Institute of Neurological Sciences and Psychiatry, and Faculty of Medicine, Hacettepe University, Ankara, Turkey

Full list of author information is available at the end of the article
}

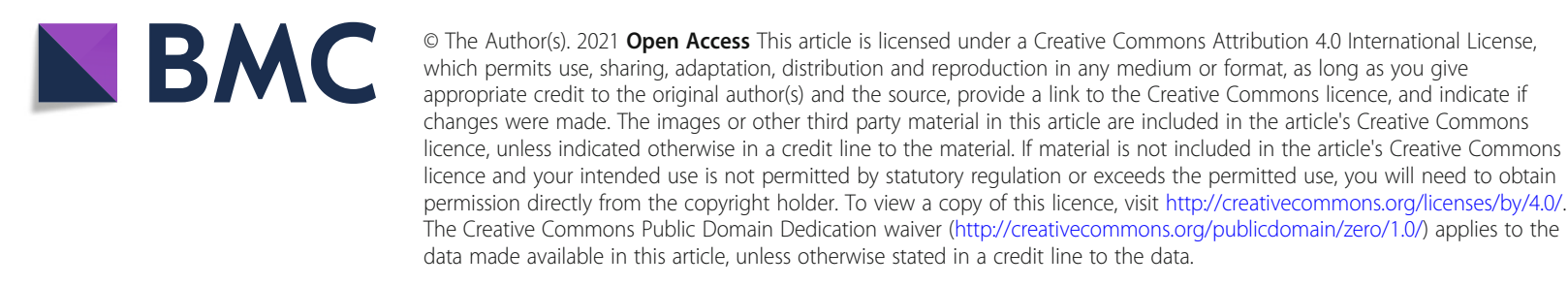




\section{Background}

Pain is generally concomitant with an inflammatory reaction of varying intensity at the site where the nociceptive fibers are activated. Migraine is probably no exception; there is ample experimental evidence, mostly from rodents, suggesting that the nociceptive trigeminocervical afferents mediating the headache can be activated by a sterile meningeal inflammatory process [1]. This process may directly originate within the meninges or be triggered by intrinsic brain activity such as cortical spreading depolarization (CSD) although debated [1-3]. Evidence from studies on mice and rats suggests that a parenchymal neuroinflammatory signaling between neurons, astrocytes and microglia, which eventually migrates to the meninges $[2,4-11]$, could be the potential link communicating a non-homeostatic event in the insensate brain to pain-sensitive meninges. Recent clinical imaging studies have provided supporting evidence for the presence of parenchymal as well as meningeal inflammation in migraine patients [12, 13]. In this review, our goal is to briefly summarize the current understanding of meningeal neurogenic inflammation and then focus on parenchymal inflammatory signaling in more detail. We should note from the beginning that these selflimited, physiological inflammatory responses should not be considered identical to conventional inflammation seen under pathological conditions despite shared mechanisms.

\section{Meningeal neurogenic inflammation and nociceptor activation}

Prolonged activation and sensitization of primary and central nociceptors within the trigeminocervical complex are thought to underlie the throbbing headache and allodynia during migraine. Rodent experiments suggest that a sterile meningeal inflammation initiated by release of peptides from trigeminocervical $\mathrm{C}$-fibers and activation of resident inflammatory cells (mast cells, macrophages and dendritic cells) could contribute to sustained activation and sensitization of meningeal nociceptors [14-17]. Supporting these experimental findings, the association of meningeal inflammation with migraine headache has recently been shown by a positron emission tomography - magnetic resonance imaging (PET-MRI) study of 11 migraine patients using a highly sensitive inflammatory tracer [(11) C]PBR28 [13] (Fig. 1). Despite significant differences between species (e.g. the dominant peptide type expressed in nociceptors), it is likely that a form of subtle inflammatory reaction is required as a common mechanism to sustain stimulation of trigeminocervical nociceptive fibers for hours and even days following initial activation [16, 18]. Available evidence suggests that this inflammatory signaling may take place in the trigeminocervical ganglia as well as meninges and might involve central nociceptive pathways on chronification of headache $[19,20]$.

Meningeal nociceptive fibers can release a number of vasoactive peptides including calcitonin gene-related

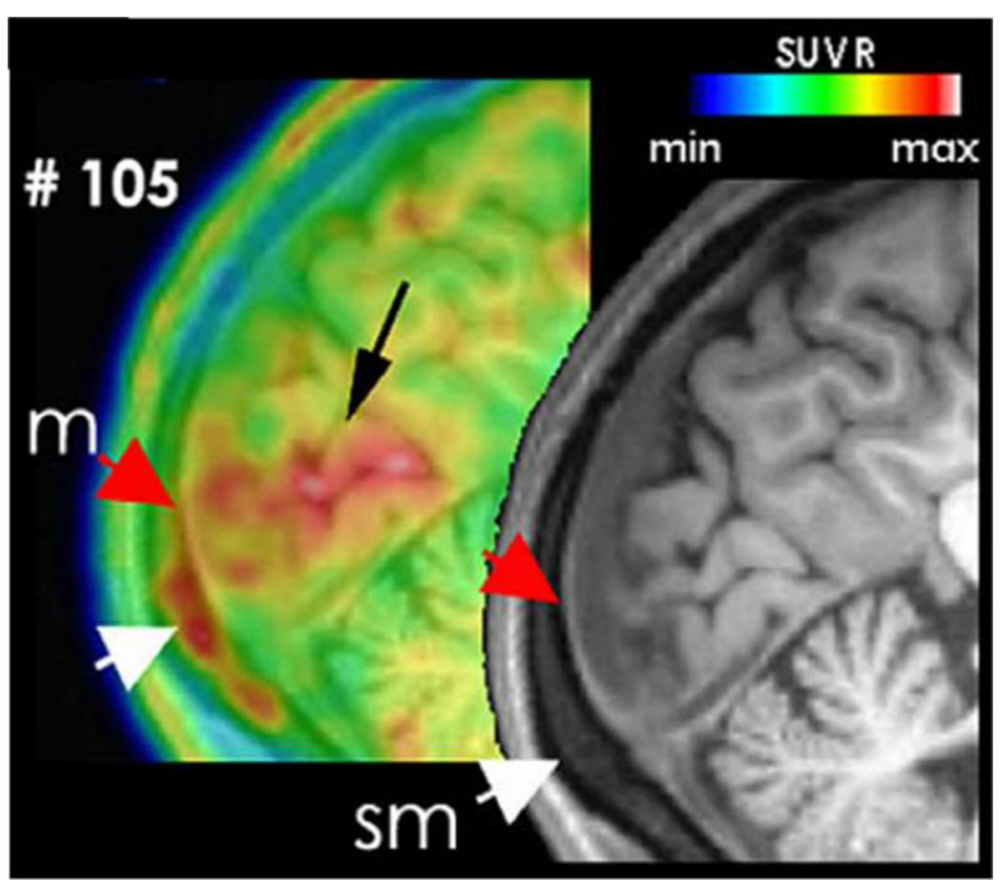

Fig. 1 [(11) C]PBR28 PET/MRI showing inflammatory activity in the occipital cortex (black arrow), overlying meninges (red arrows), and bone marrow (white arrows) in a patient suffering from migraine with visual aura attacks (from [13] with permission) 
peptide (CGRP), pituitary adenylate cyclase-activating polypeptide (PACAP), substance $\mathrm{P}$ and neurokinin-A upon prolonged activation [1, 21]. By way of a monosynaptic reflex between the trigeminal nucleus caudalis and superior salivatory nucleus in brain stem, parasympathetic nerve fibers around meningeal vessels are concomitantly activated, releasing vasointestinal peptide (VIP), PACAP and acetylcholine [1, 22]. This parasympathetic reflex is thought to mediate the middle meningeal artery (MMA) dilation lasting about an hour in the wake of CSD [2, 23, 24]. Its short duration suggests that MMA dilation is not directly involved in headache but it still could be a measurable indicator of early trigeminovascular activation. This brief change in MMA diameter may have evaded detection in patients during spontaneous migraine attacks with MR angiograms, as patients were scanned several hours after attack onset $[25,26]$. Indeed, MMA dilation in migraine has only been recorded at the initial phase of attacks induced by agents like CGRP or cilostazol [27, 28], which was significantly larger on the side ipsilateral to the pain unlike the dilations observed in intracranial arteries as a consequence of the direct vasodilatory actions of the agents used. In line with the view that MMA dilation may not be directly related to nociception, recent experimental studies have shown that systemically given CGRP antagonist, fremanezumab did not affect post-CSD MMA dilation and dural plasma protein extravasation (that has a parallel time course to MMA dilation) yet inhibited Ad-fiber mediated nociception [24, 29]. This is in contrast to action of triptans, which inhibit CGRP release from nociceptors, hence, suggests that triptans and CGRP antagonists may have different sites of actions on the bipolar trigeminocervical nerves (e.g. presynaptic varicosities or Ranvier nodes of peripheral meningeal branches or the ganglion) and dural inflammatory cells although they lead to similar pharmacological endpoints [19]. Among the peptide mediators released, CGRP is the one with the best documented role in migraine pathophysiology, because, CGRP concentration in plasma of jugular vein significantly increases during migraine attacks [30], intravenous CGRP infusion triggers migraine-like episodes in migraineurs [31] and anti-migraine treatments targeting either CGRP release (triptans) or CGRP peptide or its receptor (CGRP antagonists) are clinically effective [32].

Several lines of experimental evidence suggest that activation of inflammatory cells such as mast cells, macrophages and dendritic cells contribute to meningeal neurogenic inflammation, at least in rodents [14-17] (Fig. 2). Dural macrophages activated by a single CSD reportedly retract their processes, assume a transient (20-50 min) circular phenotype and stay in close proximity to transient receptor potential cation channel subfamily (TRP) V member 1 (TRPV1)-positive meningeal nociceptors [17]. Dural mast cells are lined up along nociceptive fibers, suggesting a functional collaboration between them. Experiments in rodents have shown that mast cell activation contributes to activation of nociceptors by releasing several algesic mediators such as serotonin and prostaglandin $I_{2}$ [33]. Tryptase is also secreted by mast cells, which activates the protease-activated receptors (PAR) found on dural afferents and causes

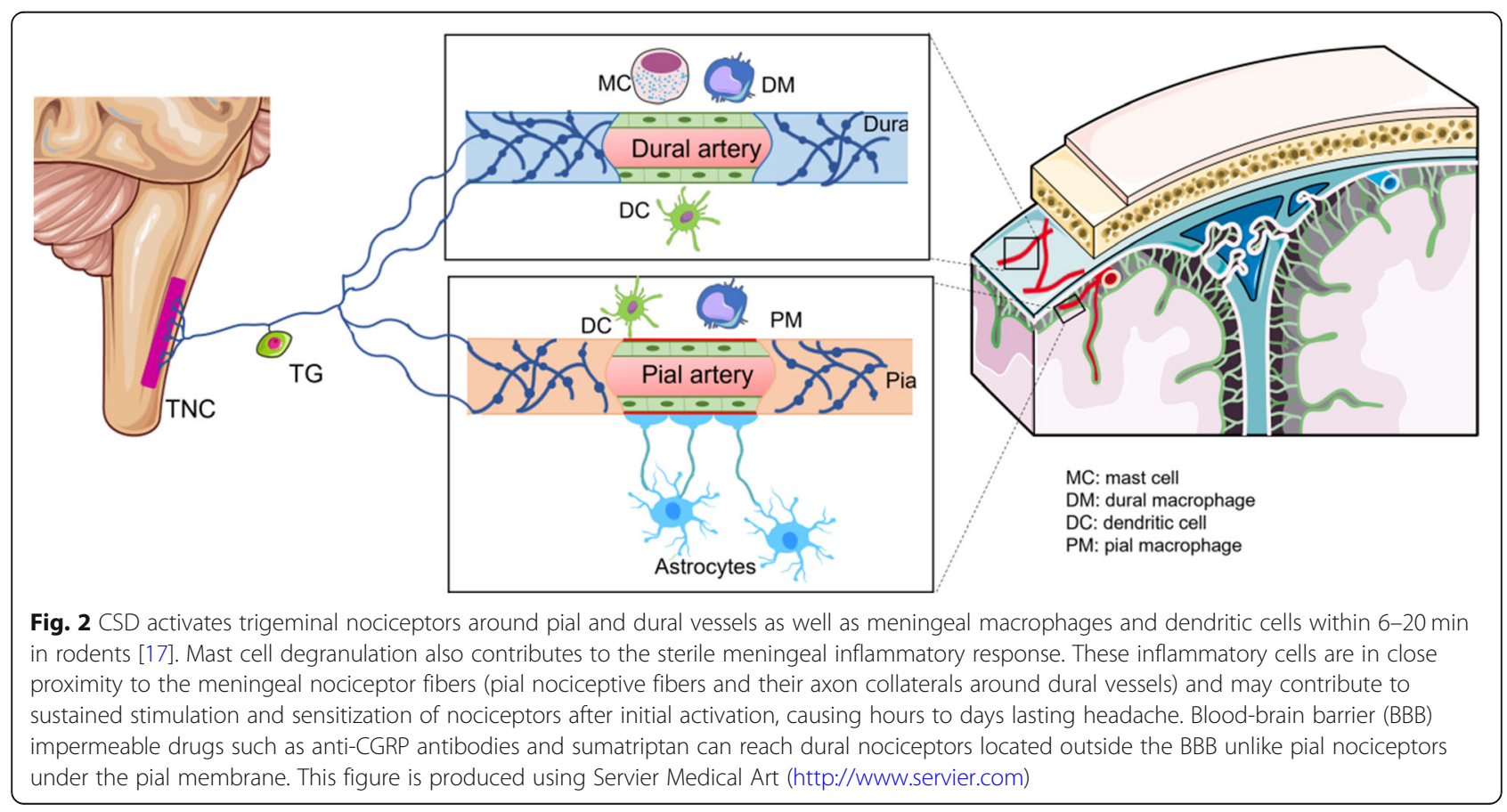


migraine-like pain behaviors in mice [34-36]. Moreover, mast cells express purinergic receptors [37], which can be activated by adenosine triphosphate (ATP) elevated in the extracellular medium during inflammatory conditions. In mast cell-deficient animals, extracellular ATP-induced nociceptor firing is significantly weaker [38]. PACAP and glyceryl-trinitrate (GTN), both of which cause migrainelike headaches in humans are potent inducers of mast cell degranulation [39, 40]. VIP, Substance P, but not CGRP, degranulate human mast cells in vitro [41]. Although no CGRP receptor expression was detected in human mast cells [42], macrophages and dendritic cells [17] express CGRP receptors $[43,44]$ and can release mediators capable of activating nearby mast cells. The parasympathetic reflex can also contribute to mast cell activation by releasing PACAP and VIP. However, the evidence from humans for these inflammatory cellular reactions identified in experimental animals is yet incomplete. For instance, Khan et al., studied uptake of paramagnetic particles by macrophages in patients within $24 \mathrm{~h}$ of a migraine without aura (MO) attack [45], unfortunately however, their resolution allowed imaging macrophages only in the parenchyma, not in the meninges. Not surprisingly, they did not find increased macrophage activity in the pain processing hemisphere because the parenchymal neuroinflammatory signaling in migraine likely does not involve participation of inflammatory cells as discussed below.

As noted above, a strong support for involvement of vasoactive neuropeptides and sensory fibers in migraine pathogenesis is based on the success of anti-CGRP monoclonal antibodies, triptans and ditans in the clinic. CGRP antagonists inhibit CGRP or its receptors, whereas ergots and 5-hydroxytriptamine 1B/1D $\left(5 \mathrm{HT}_{1 \mathrm{~B} / 1 \mathrm{D}}\right)$ receptor agonist triptans, as well as the novel 5- $\mathrm{HT}_{1 \mathrm{~F}}$ agonist lasmiditan suppress CGRP release from C-fibers [46-48]. Development of clinically useful triptans and CGRP antagonists is a striking example of how animal models of meningeal neurogenic inflammation provided information about neuropeptides that was instrumental and highly informative for clinical drug discovery. The successful relief of headache by monoclonal CGRP antibodies, which cannot permeate the bloodbrain barrier (BBB) due to their large size, point to the significant role of CGRP in migraine nociception although the precise site of action is yet not clear [19]. Alleviation of migraine headache with sumatriptan that is also poorly BBB-permeable is in line with the effect of antibodies against CGRP and its receptor. These findings altogether suggest a site of action outside the BBB for triptans and CGRP antagonists either in the dura, the trigeminal ganglion or both. On the contrary, the clinical inefficiency of neurokinin-A antagonists that inhibit plasma protein extravasation in rodents led to the suggestion that the meningeal neurogenic inflammation might be a mere indicator of nociceptor activation but not the cause of headache [49-52]. It was further argued that the peripheral site of action of acute migraine drugs did not necessarily exclude the role of central mechanisms because a primarily intrinsic brain dysfunction could secondarily activate the peripheral trigeminal mechanisms.

Similarities (e.g. throbbing nature, photo and phonophobia) to headaches of subarachnoid hemorrhage or meningitis, known to be caused by meningeal irritation and inflammation, point to the meningeal nociception as the substrate of migraine headache as well [53]. However, despite the shared cascade of events, the intensity of inflammatory reaction is dramatically different between the two conditions. For example, while meningitis causes manifest gadolinium contrast enhancement in MRI, no enhancement has been detected during experimentally induced dural neurogenic inflammation [5456] and there are is only a few case reports of contrast enhancement observed during severe familial hemiplegic migraine (FHM) attacks or prolonged aura [57-59]. The subtle inflammatory changes in meningeal neurogenic inflammation are therefore difficult to detect clinically by using routine neuroimaging methods. Indeed, a sensitive inflammatory tracer and sophisticated PET-MRI technology were necessary to be able to show this inflammatory activity in migraine patients suffering from frequent attacks [13].

\section{Origin of meningeal neurogenic inflammation}

Activation and sensitization of trigeminocervical nociceptors, as part of an acute sterile inflammation, can take place at the level of meninges or the trigeminocervical ganglia, without any intrinsic brain involvement [60, 61]. Indeed, some migraine headaches may be initiated by direct activation of meningeal nociceptors with environmental irritants. For example, umbellulone evaporating from the leaves of headache tree (Umbellularia californica) is thought to stimulate TRP subfamily A member 1 (TRPA1) channels on meningeal nociceptors and thus cause headache [62]. Besides this direct mechanism of nociceptor activation, some irritants may act by inducing meningeal mast cell degranulation [15]. Another activator of the meningeal mast cells, GTN [39, 63] induces headache within 4-6 h after administration to migraineurs $[64,65]$ and meningeal neurogenic inflammation in rodents [63].

As noted above, a transient central dysfunction translated to headache by the trigeminocervical complex and its peripheral nociceptors are considered the most likely mechanism initiating migraine headache. A cerebral origin is indeed suggested by presence of several prodromal neurological symptoms preceding the headache [66]. Based on these, the central 'migraine generator' theory has been proposed [67-70]. PET studies of spontaneous 
or induced migraine attacks pointed to the brain stem areas including the periaqueductal gray matter and/or dorsolateral pons as potential trigger zones [67, 70-73]. However, considering that these areas cover several brain stem nuclei or neuronal populations having opposing roles in pain modulation, the resolution of the images was not sufficient to make a compelling argument for a pain-generating brain stem dysregulation [74, 75]. Imaging studies also disclosed an increased hypothalamic activity during migraine attacks, which led to suggestion of the hypothalamus as a potential trigger zone [76-78]. Indeed, an abnormal activity in hypothalamic nuclei and increased connectivity with thalamic and brain stem nuclei have been documented in the premonitory phase of migraine, as early as $24 \mathrm{~h}$ before symptomatic attack $[78,79]$. This early hypothalamic activation is consistent with prodromal symptoms like appetite change, sleep abnormalities or autonomic alterations. However, the headache generator hypothesis currently lacks a convincing explanation for why a trigger zone should be present specifically for the trigeminal ophthalmic nociceptive system associated with migraine, whereas no such mechanism exists for neighboring areas transmitting/modulating the nociceptive impulses from rest of the body. Therefore, other intrinsic brain events arising in the parenchyma under suboptimal homeostatic conditions should also be considered for subsequent activation of peripheral and central nociceptors and, meningeal neurogenic inflammation.

In line with the latter view, although debated, migraine aura appears to be one of the triggers of the meningeal nociception [3, 16, 80, 81]. Several key experimental findings support this possibility: For example, it has been shown that CSD, the neurophysiological correlate of migraine aura [82], can lead to vasodilation, plasma extravasation and mast cell degranulation in dura about 20 min after a single CSD in rodents [2, 23, 24]. These changes can be prevented by trigeminal nerve denervation, indicating that they are caused by activation of the trigeminal nerve by CSD [23]. Indeed, both the trigeminal ganglion and second-order neurons in brain stem have been shown to start firing around $20 \mathrm{~min}$ after CSD in the rat [83-87]. Supporting animal experiments, headache also emerged within $35 \mathrm{~min}$ after the experimentally induced auras in migraineurs by hypoxia or by exercise (alone or combined with photic stimulation) or by photic stimulation [82, 88]. Focal hypoperfusion/hypoxia-induced headaches following an aura are one of the earliest symptoms of hereditary vasculopathies such as CADASIL $[89,90]$.

Conforming with the experimental findings, meningeal contrast enhancement was recorded with MRI during severe FHM or prolonged aura attacks [57-59] and, albumin leakage to dura was detected by single-photon emission computed tomography imaging during a migraine attack in a non-familial migraine case [91]. However, the most compelling evidence has recently been obtained by using a sensitive PET inflammation marker ([(11) C]PBR28), showing clear meningeal tracer uptake in 11 of 11 patients suffering from migraine with aura [13]. Importantly, the labeling was most prominent over the occipital cortex generating the visual aura and lasted several days after a migraine attack. The tracer uptake was strong enough to be visualized in single patients, creating the opportunity to test various hypotheses regarding the role of meningeal inflammation in migraine (e.g. whether it is suppressed by triptans and CGRP antagonists). Tracer uptake was extended into the overlying bone marrow, raising the interesting possibility that inflammatory bone marrow cells might also contribute to dural inflammation. This finding is also supported by the identification of direct vascular channels in rodents and humans, connecting skull bone marrow to the brain surface and meninges and allowing migration of myeloid cells [92].

About 2/3 of migraineurs, on the other hand, do not experience aura before headache $(\mathrm{MO})$, which requires identification of brain dysfunctions other than CSD that can also lead to trigeminovascular activation. In fact, this need led to the hypothesis of a central dysfunction in pain pathways as discussed above. Alternatively, silent (asymptomatic) CSDs limited to gyri outside the visual and sensory cortices have been proposed to underlie MO attacks [93, 94]. The activation of parenchymal inflammatory signaling pathways and subsequent meningeal inflammation by cortical disturbances other than CSD has been proposed as another possibility [95]. According to this hypothesis, a mismatch between the rapidly escalating metabolic demand during intense glutamatergic transmission and synaptic energy supply can initiate the inflammatory signaling cascade and cause headache [96]. Migraine triggers such as fasting, sleep deprivation and hormonal changes may predispose to such a mismatch by impacting astrocytic energy supply mechanisms at transcriptional level [95-97]. For instance, sleep deprivation has been shown to lead to inadequate utilization of astrocytic glycogen because of the transcriptional changes induced that favor glycogen synthesis over glycogen breakdown [95, 96]. Glycosyl units liberated from glycogen are preferentially used over glucose for the uptake of extracellular potassium and glutamate by astrocyte processes due to the differential kinetics of enzymes involved and rates of glucose transport versus glycosyl liberation [95-97]. The same mechanism has also been shown to lower the CSD threshold in rodents by causing insufficient clearance of extracellular potassium and glutamate, hinting clues for emergence of migraine with and without aura attacks in the 
same individual by using a final common pathway [9597]. Clinically supporting a potential role of metabolic perturbation in MO, headache emerged before as well as after the aura in migraineurs subjected to prolonged hypoxia [88]. The extensive literature about the potential role of a cerebral energy imbalance in migraine has recently been reviewed $[98,99]$.

\section{Parenchymal neuroinflammatory signaling}

Several groups have reported a parenchymal inflammatory response to CSD, which might migrate to meninges and activate the trigeminovascular system and meningeal inflammation [2,5-11]. Of note, this is simply a noncellular, molecular inflammatory signaling cascade reporting the suboptimal homeostasis in brain but not an overt inflammation as seen, for example, in multiple sclerosis or around glial tumors. Such parenchymal signaling appears to be a prerequisite for migraine attacks starting within the brain except those initiated by direct activation of meningeal nociceptors. CSD-induced flux of algesic mediators such as $\mathrm{H}^{+}$, ATP and nitric oxide (NO) from interstitium to perivascular and subarachnoid spaces can activate perivascular pial nociceptors [23]. Indeed, in rats, firing of a group of neurons in trigeminal ganglion and nucleus caudalis concomitantly with CSD has been recorded, which can account for the auras coincident with headache [17, 83-87]. However, most of the nociceptive units started firing $15 \mathrm{~min}$ after a CSD wave when the tissue homeostasis had already been restored, in line with the clinical observation that headaches being delayed by 15-20 min after majority of migraine auras. This delay in dural nociceptor firing also conforms to the slowly rising MMA blood flow in the wake of CSD in rats and mice [2, $23,24]$. A $12-20$ min delayed activation of dural macrophages and dendritic cells, following early activation of pial macrophages has also been proposed to explain this time lag after CSD [17].

Supporting the hypothesis of parenchymal inflammatory signaling, a recent PET/MRI study showed widespread uptake of an inflammatory tracer in the brains of 13 patients having frequent migraine with aura attacks [12]. According to the observations made in mice and rats, neural stress created by high extracellular potassium, glutamate and intracellular calcium as well as swelling during a single CSD leads to opening of pannexin 1 (Panx1) large-pore channels and release of interleukin-1 $\beta$ (IL-1 $\beta$ ) and high mobility group box protein 1 (HMGB1) from neurons [2] (Fig. 3). These proinflammatory mediators cause nuclear translocation of the transcription factor nuclear factor-kappa B (NF-kB) in astrocytes and induce transcription of inflammatory enzymes and cytokines, which likely results in synthesis and release of prostanoids, cytokines, and NO from astrocytes to the perivascular and subarachnoid spaces [2].
The inflammatory mediators can directly reach nociceptive fibers around pial vessels over the glia limitans through a menigeo-astroglial network of interconnected cellular processes [100] (Fig. 3) or by way of cerebrospinal fluid (CSF) fluxes toward the surface in perivascular spaces. Axon collaterals from pial perivascular nociceptive fibers are thought to activate dural nociceptors and trigger the inflammatory signaling observed in rodent studies (Fig. 2). Indeed, an overt inflammatory tracer uptake in meninges overlying the occipital cortex was detected in the PET/MRI study of migraine with aura (MA) patients as mentioned above [13]. In the sections below, we will review the main elements of this parenchymal inflammatory cascade in more detail.

One advantage of the parenchymal inflammatory signaling hypothesis is that it can explain activation of meningeal nociceptors in the absence of CSD (in MO) as well as with CSD (in MA). For example, migraine triggers such as sleep deprivation or acute psychological stress induce transcriptional changes in astrocytes that direct glucose in astrocyte processes preferentially to glycogen synthesis, thereby, hindering glutamate and potassium clearance during rapidly escalating intense neuronal activity because glycogen-derived glycosyl units are essential to fuel astrocytic uptake mechanisms $[95,96]$. This synaptic activityrelated neuronal stress has been shown to initiate the parenchymal signaling cascade by opening of the neuronal Panx1 channels, causing caspase-1 activation and HMGB1 release in the absence of CSD in the mouse [95]. Thus, migraine triggers could potentially activate the parenchymal inflammatory signaling pathway and induce headache without needing CSD (i.e. aura).

Although multiple CSDs were previously proposed to be necessary for headache generation in rodents [101, 102], recent behavioral tests clearly showed that a single CSD evoked by noninvasive methods was sufficient to generate headache within an hour $[103,104]$ as suggested by previous electrophysiological recordings from dural afferents in rats [17, 83-87]. Of note, inflammatory response is expectedly heightened after multiple CSDs and is known to lead to activation of microglia, thus, can exhibit a more complex expression profile, which may be more akin to the inflammatory reaction in patients suffering from frequent migraine with aura attacks $[9,11,105,106]$. Whereas multiple CSDs are useful as an experimental tool to disclose CSD-induced subtle changes, it should be kept in mind that, typically, a single CSD causes most of the auras in humans and, the associated hemodynamic changes matching the symptoms are localized to a single lobe or a few gyri, as captured with functional MRI or PET performed within 30 min of aura onset [82, 93, 107112]. However, aura does not always lead to headache in patients, suggesting that, to be able to induce pain, CSDinduced inflammatory signaling has to coincide with a 


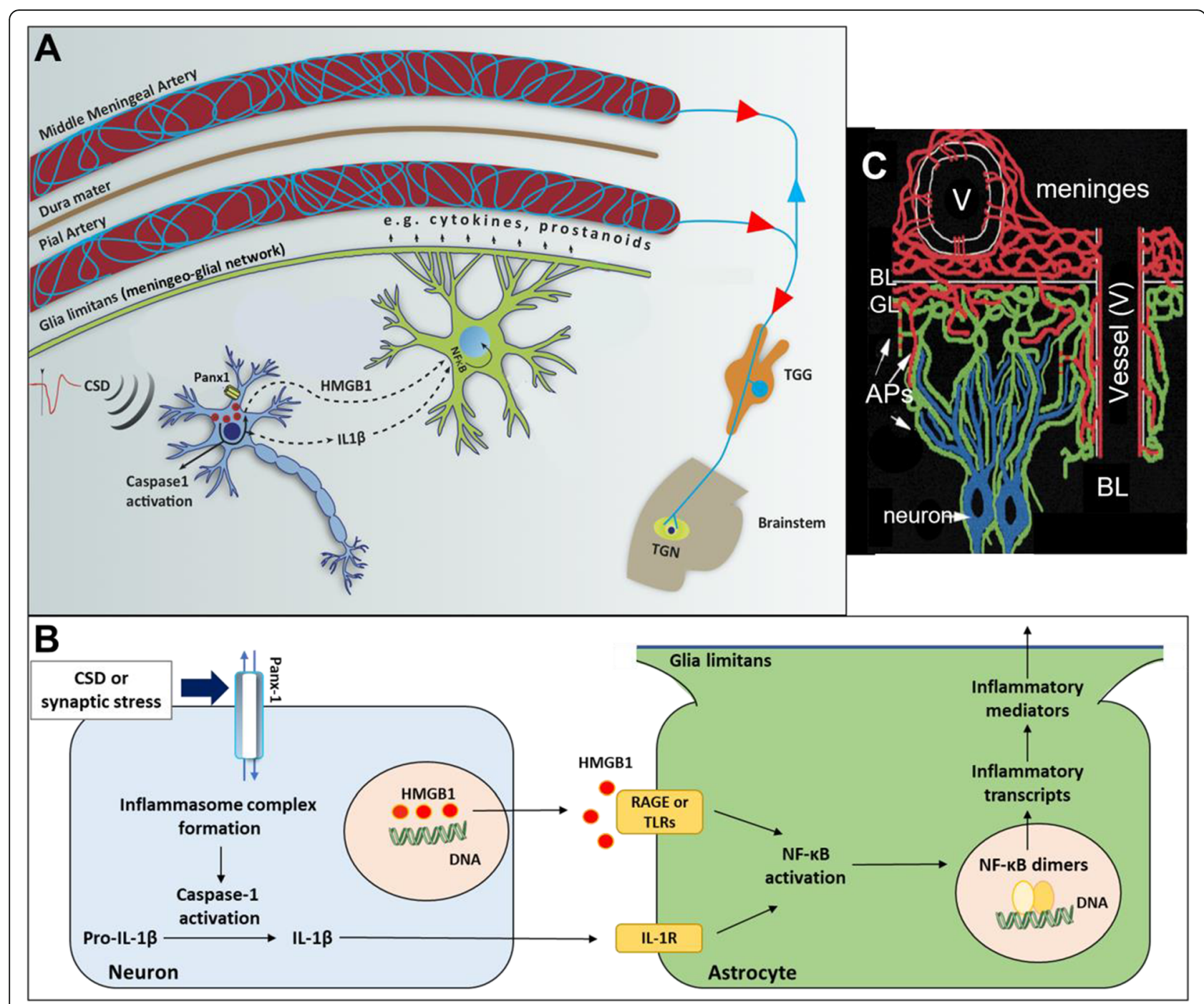

Fig. 3 Neuronal Panx 1 channel opening after CSD initiates a neuroinflammatory cascade, characterized by inflammasome formation and caspase1 activation in neurons followed by release of HMGB1 and IL-1B, which trigger NF-KB nuclear translocation in astrocytes. A, B NF-KB leads to proinflammatory transcriptional activity and secretion of nitric oxide, cytokines and prostanoids from astrocyte endfeet, reaching meningeal nociceptors by way of meningo-astroglial network (C) to stimulate them (from [2 and 100], with permission). In A, red labels show agents used to inhibit each step in the inflammatory cascade and red circles represent propidium iodide (PI) influx through open Panx1 channels

period when the somatosensory threshold is low. Fluctuations in the somatosensory threshold throughout the migraine cycle were previously shown with repeated functional MRIs (fMRI) during trigeminal stimulation and the extensive literature on migraine thresholds has recently been reviewed [113, 114]. Furthermore, pain threshold is well known to show inter and intra-individual variability and is modulated by several biological factors (e.g. genetic and hormonal). Indeed, some people never suffer from headaches at all [3].

\section{Neuronal stress sensors - Pannexin channels}

Pannexins are membrane proteins harboring a largepore ion channel. Although they are structurally similar to gap junction connexins, they assemble as membrane hemichannels without forming cell-to-cell coupled conduits. Of the 3 types of pannexin channels, Panx 1 and Panx 2 are present in the nervous system. Panx 1 is widely expressed in both excitatory and inhibitory neurons as well as oligodendrocytes, astrocytes and microglia [115]. In neurons, it is mainly localized at the postsynaptic membrane [116] and functions as a modulator of glutamatergic transmission and a sensor for stressful conditions [117-119]. For example, when postsynaptic metabotropic N-methyl-D-aspartate (NMDA) receptors are activated, Src family of tyrosine kinases phosphorylate Panx1, allowing release of anandamide through Panx1 channel, which inhibits $\mathrm{Ca}^{2+}$ influx to the 
presynaptic terminal and glutamate release, hence, stabilizes excitatory activity [120]. When extracellular potassium and glutamate are high and NMDA receptors are intensely stimulated, Panx1 activation leads to inflammasome formation in neurons and IL- $1 \beta$ release, whereas more severe conditions jeopardizing cell survival cause caspase-mediated cleavage of $\mathrm{C}$-terminal domain and persistent pore opening [121-123]. Panx1 activation by caspase-mediated cleavage releases large amounts of ATP to the extracellular medium, which recruits immune cells for clearance of apoptotic fragments [124].

Panx1 channels can be activated by various signals including increases in extracellular $\mathrm{K}^{+}$, glutamate and intracellular $\mathrm{Ca}^{2+}$ concentration [125], NMDA receptor stimulation [121], c-Jun N-terminal kinases, Src family of tyrosine kinases [126] and mechanical stress (e.g. spine swelling) [127]. Panx1 has two pore- opening states; a low-conductance ion channel with selective $\mathrm{Cl}^{-}$permeability (no neuronal function is known) and a largeconductance nonselective channel permeable to molecules up to $900 \mathrm{Da}$, allowing considerable potassium and ATP efflux and, possibly, calcium influx [119, 128]. The latter feature is used to detect Panx1 opening with membraneimpermeant fluorescent dyes smaller than $900 \mathrm{Da}$ like propidium iodide or YoPro-1 [124, 129]. This method has been instrumental to disclose the CSD-induced Panx1 activity in the brain $[2,10]$ (Fig. 3). The exact mechanism of how neuronal Panx1 channels open in large-conductance state after CSD or synaptic metabolic stress is not entirely clear. High extracellular $\mathrm{K}^{+}$and glutamate, NMDA receptor overactivation, high intracellular calcium, neuronal swelling may contribute to Panx1 large channel opening $[2,95]$. It has recently been shown that CSD-induced stimulation of NR2A type NMDA receptor subunits activates Src-family kinases, which phosphorylate Y308 near the intracellular C-terminal, hence, promotes opening of Panx1 channels [10].

ATP released to the extracellular environment through the Panx1 large pore channels can activate nearby P2X7 receptors [130, 131]. Like Panx1 channels, P2X7 receptors are also able to switch to large conductance pore opening and activate inflammasome formation [130-132]. At least in macrophages, these two channels together are considered as a functional unit both capable of triggering formation of the inflammasome complex $[125,133,134]$. Whether or not neurons express P2X7 is controversial and the recent data do not support the expression of P2X7 in mature neurons in adult rodents [135-137]. Any close collaboration between neuronal Panx1 and P2X7 receptors on nearby astrocytes [138] and microglia processes [139] remains to be investigated.

Experimentally, it is possible to inhibit Panx1 or purinergic receptor activity with agents like carbenoxolone, probenecid, mefloquine ${ }^{10}$ panx peptide, disodium $4,4^{\prime}$ - diisothiocyanatostilbene-2,2' -disulfonate or brilliant blue G [140]. Probenecid and mefloquine are clinically registered drugs [129], however, no reports have been published on their potential effect on migraine at the currently used doses although they are widely prescribed for gout and malaria treatment for many decades.

\section{Inflammasome complex formation and release of IL-1 $\beta$ and HMGB1 from neurons}

Inflammasome complex formation is the downstream step to Panx1 channel activation. Inflammasomes are multimeric protein complexes that oligomerize in response to infectious agents or homeostatic disruptions. Inflammasome formation is a common step initiating most neuroinflammatory conditions by serving as a molecular machinery processing proinflammatory mediators to their active forms. An inflammasome complex is formed by clustering of the node-like receptors (NLRs), which detect the exogenous pathogen-associated molecular patterns (PAMPs) or endogenous damageassociated molecular patterns (DAMPs), and the adapter molecule, apoptosis-associated speck-like protein containing a C-terminal caspase recruitment domain (ASC) $[141,142]$. Pro-caspase-1 dimerizes on the inflammasome complex and cleaves itself to release the active caspase- 1 , which mediates the proteolytic cleavage of pro-IL- $1 \beta$ in the cytoplasm to yield the active IL- $1 \beta$. Inflammasome activation is also linked to HMGB1 translocation from nucleus to cytoplasm [143, 144]. Components of the inflammasome complexes are expressed in CNS cells $[145,146]$. After CSD, inflammasome complex is rapidly formed as shown by appearance of the cleaved form of caspase- 1 in neurons and detection of released IL-1 $\beta$ in CSF [2](Fig. 3). An increase in IL-1 $\beta$ expression as early as 10 min after a single noninvasively (optogenetically) triggered CSD has also been reported, which is followed by expression of several other pro-inflammatory genes [11]. However, the latter transcriptional changes detected in the cortical extracts may also reflect the NF-kB-induced transcriptional changes in astrocytes as discussed in the next section.

Parenchymal IL-1 $\beta$ production could also be a significant step leading to meningeal nociceptor activation in migraine without aura (i.e. without CSD) $[95,96]$. Indeed, MO attacks are seen in patients with cyropyrinassociated periodic syndromes, in which IL- $1 \beta$ is overproduced due to mutations in the inflammasome component NLRP3. Interestingly, these migraine attacks are suppressed with IL1 receptor antagonist anakinra [147149]. Further supporting a role for parenchymal inflammatory signaling in MO, IL-1 $\beta$, prostaglandin $E_{2}$, tumor necrosis factor- $\alpha$ (TNF- $\alpha$ ), IL- 6 , and nitrite levels in the internal jugular vein (which drains mainly the brain 
parenchyma but not the meninges) were found to be elevated within the first hour of a MO attack [150-152].

HMGB1 is one of the non-histone proteins that binds to DNA in the nucleus and is expressed in high amounts by almost all cells [153]. It plays a role in chromosome stabilization, nucleosome mobility, DNA repair and control of transcription by binding to DNA [153]. Moreover, HMGB1 belongs to the family of alarmin proteins that initiate a rapid inflammatory response upon release from the cell [154]. HMGB1 passively leaks from necrotic or damaged cells but it can also be actively transported out of the cell after an inflammatory stimulus such as cell swelling, tissue injury or infection $[155,156]$. In such cases, its three-dimensional structure changes by acetylation, phosphorylation or methylation of different amino acids [156]. This structural change allows the nuclear export signal to be exposed and leads to translocation of HMGB1 from nucleus to cytoplasm. HMGB1 can activate various inflammatory pathways including NF- $\mathrm{KB}$ in nearby cells bearing receptor for advanced glycation end products (RAGE) and toll-like receptors (TLRs) [156, 157].

About half of the neuronal nuclei lose their HMGB1 immunoreactivity right after a single CSD, whereas glial nuclei are not affected $[2,158]$ (Fig. 3). Single optogenetically-induced CSD also causes a comparable HMGB1 release to pinprick- or $\mathrm{KCl}$-induced single CSDs (unpublished data), ensuring that HMGB1 release was caused by CSD but not experimental injury. The best available method to show CSD-induced HMGB1 release appears to be the immunohistochemistry (i.e. loss of nuclear HMGB1 immunoreactivity), whose specificity was validated by showing prevention of the CSD-induced NF$\kappa B$ translocation in astrocytes with a neutralizing antibody against HMGB1 or by BoxA fragment of HMGB1 that shows antagonistic activity or by HMGB1-shRNA [2]. Some of the released HMGB1 leaks into CSF, however, it reaches detectable levels with Western blotting only after multiple CSDs. Furthermore, collecting CSF from small rodents with a stable intracerebroventricular cannula without injuring the brain is challenging. This small HMGB1 loss from brain tissue could also be detected in Western blots of cortex extracts as a decrease in HMGB1 levels $3 \mathrm{~h}$ after multiple, but not single, CSDs giving the impression that only multiple CSDs could cause HMGB1 release [5]. After a single CSD induced by either pinprick or $\mathrm{KCl}$ or optogenetically, NF- $\mathrm{kB}$ rapidly translocates to the nucleus (i.e. becomes activated) in astrocytes in response to HMGB1 released from neurons in the mouse brain [2, 158-160] (Fig. 3).

HMGB1 has also been linked to several other painassociated conditions. HMGB1 translocation in spinal cord neurons contributes to bone cancer-related hyperalgesia [161]. HMGB1 can directly induce pain, as shown by subcutaneous injection of HMGB1 to the paw or application over the sciatic nerve [162, 163]. HMGB1 expression is reportedly increased in the spinal cord in diabetic neuropathic pain [164] and mechanical compression pain, in which anti-HMGB1 neutralizing antibodies reverse the pain-related behavior in rodents [165].

\section{Astrocyte and microglia activation and NF-KB pathway}

Release of IL-1 $\beta$ and HMGB1 activates the NF- $\mathrm{kB}$ pathway in neighboring cells. Transcriptional NF- $\kappa B$ activity in astrocytes and microglia is particularly important for orchestrating the neuroinflammatory response; however, the timing and pro or anti-inflammatory nature of transcriptional activity may vary between astrocytes and microglia. The NF- $\mathrm{BB}$ transcription factor family operates by combining five subunits in pairs [166, 167]. These subunits are p65, cRel, RelB, p52, and p50. Each subunit contains a region called Rel homology domain [166]. This region contains the specific amino acid sequence that allows the subunit to form a pair, enter the cell nucleus and bind to DNA. The transactivation zone necessary for transcription is found only in the p65, cRel, and RelB subunits. Therefore, when pairs that do not contain one of these subunits (e.g. p50/p50) are attached to DNA, they only modify activities of the transcriptioninducing pairs [166]. The NF-KB signaling operates through two alternative pathways, classical and nonclassical. While the classical pathway plays a role in innate immunity and cell survival, the non-classical pathway is effective in acquired immune response. In conditions that create a sterile immune response such as inflammatory signaling induced by CSD, the classical pathway is activated [2, 9]. Effective subunits in this pathway are p65, p50 and cRel [168].

Pro-inflammatory mediators released from neurons or astrocytes activate microglia, the main immune cells of the CNS. After multiple CSDs, overt microglial activation is delayed by $24 \mathrm{~h}$ and depends on TLR2/4 [169]. These microglia are hypertrophic, exhibit increased motility/migration and phagocytic activity, reactive oxygen species production and IL- $1 \beta$ and TNF- $\alpha$ secretion $[105$, 106, 170-173]. Importantly, these changes are observed only after multiple CSDs but not a single CSD. The delayed emergence of inflammatory changes after the induction of CSD suggests that activated microglia may function in elimination or repair of the injured (swollen) dendritic spines during repeated CSDs [106, 174, 175]. Interestingly, naïve FHM mutant mice show microglial activation characterized with increased branching even under baseline conditions [176]. This may be caused by the recurrent spontaneous CSDs in these animals. Moreover, microglia may also play a downregulatory role in resolution of the parenchymal inflammatory signaling by 
switching to an anti-inflammatory phenotype, however, this remains to be investigated [177].

\section{Clinical outlook and conclusions}

A fundamental step to further our understanding on migraine pathophysiology is to document the presence of the above-discussed mechanisms in migraine patients. Recent advances in neuroimaging techniques are promising in this regard. Detection of the meningeal inflammation over the occipital cortex exhibiting parenchymal inflammatory tracer uptake in patients suffering from migraine with visual aura is particularly encouraging, although preliminary [13] (Fig. 1). Improved tracers, if successful, can be instrumental to resolve some of the controversies on the role of meningeal inflammation in migraine. In this study, researchers took advantage of a sensitive PET ligand, [(11) C]PBR28 that detects the inflammatory activity in astrocytes and microglia by binding to the translocator protein (TSPO) located on outer mitochondrial membranes of active inflammatory cells. [(11) C]PBR28 was able to mark both CNS and meningeal involvement, as TSPO is upregulated in activated parenchymal glial cells as well as activated macrophages and peripheral immune cells. These observations are translationally relevant because experimental studies using the same radioligand showed increased uptake in the ipsilateral rat brain for up to 15 days after multiple CSDs [178]. Of note, the activity of the glia and meningeal inflammatory cells visualized by [(11) C]PBR28 uptake might not solely be caused by a pro-inflammatory state but might also involve anti-inflammatory activity because majority of the patients had their last headache attack a few days before imaging. Indeed, ongoing studies in our laboratory show that resolution of the inflammatory activity induced by a single CSD takes at least 3 days in the mouse brain $[159,160]$.

[(11) C]PBR28 PET may also provide insight into the relationship between inflammatory signaling and headache in secondary headache disorders. As in migraine, parenchymal inflammation can also play a role in post-seizure headache, as suggested by studies showing activation of the neuroinflammatory cascade in seizure models $[179$, 180]. Similarly, acute ischemia attacks are associated with headache [181]; but not always, possibly because ischemic nociceptive fibers around pial vessels become dysfunctional due to hypoperfusion of these arteries (the cause of the stroke) and, hence, cannot fire despite inflammatory mediators reaching to the pia from the ischemic brain. Indeed, headache is more prevalent after intracerebral hemorrhages and subarachnoid hemorrhage, which also activate Panx1 and downstream pathways [182].

In conclusion, experimental studies in animals and emerging imaging findings from patients warrant further research to gain deeper insight into the complex role of inflammatory signaling in headache generation. Research over the past 50 years have revolutionized our understanding of migraine, however, many unanswered questions and controversies remain. We need cutting-edge tools to directly and comprehensively study the complex nociceptive mechanisms in experimental animals and also high-resolution advanced imaging technologies to assess the significance of basic findings in the clinic. Admittedly, current experimental and clinical methods have shortcomings to provide unequivocal evidence for competing hypotheses.

\section{Abbreviations}

TSPO: 18kD translocator protein; BBB: Blood-brain barrier; CADASIL: Cerebral autosomal dominant arteriopathy with subcortical infarcts and leukoencephalopathy; CGRP: Calcitonin gene-related peptide; CSF: Cerebrospinal fluid; CSD: Cortical spreading depolarization; DAMP: Damage-associated molecular pattern; FHM: Familial hemiplegic migraine; GTN: Glyceryl-trinitrate; HMGB1: High mobility group box protein 1; IL: Interleukin; MMA: Middle meningeal artery; MO: Migraine without aura; MA: Migraine with aura; NO: Nitric oxide; NMDA: N-methyl-D-aspartate; NLR: Node-like receptor; NF-kB: Nuclear factor-kappa B; Panx: Pannexin; PAMP: Pathogen-associated molecular pattern; PACAP: Pituitary adenylate cyclase-activating polypeptide; PET/MRI: Positron emission tomography/ magnetic resonance imaging; KCl: Potassium chloride; PAR: Proteaseactivated receptor; RAGE: Receptor for advanced glycation end products; TLR: Toll-like receptor; TRP: Transient receptor potential cation channel subfamily; TNF: Tumor necrosis factor; VIP: Vasoactive intestinal polypeptide

Acknowledgements

Not applicable.

Authors' contributions

All authors contributed to drafting the manuscript. Zeynep Kaya prepared Fig. 2 and Fig. 3B. The author(s) read and approved the final manuscript.

\section{Funding}

Turgay Dalkara's research is funded by the Turkish Academy of Sciences and grants from Hacettepe University (TSA-2017-14418) and Scientific and Technological Research Council of Turkey (TÜBITAK 118S435).

Availability of data and materials Not applicable.

\section{Declarations}

Ethical approval and consent to participate

Not applicable.

Consent for publication

Not applicable.

\section{Competing interests}

The authors declare that they have no competing interests.

\section{Author details}

${ }^{1}$ Institute of Neurological Sciences and Psychiatry, Hacettepe University, Sinhiye, Ankara, Turkey. ${ }^{2}$ Institute of Neurological Sciences and Psychiatry, and Faculty of Medicine, Hacettepe University, Ankara, Turkey.

Received: 3 October 2021 Accepted: 5 November 2021

Published online: 18 November 2021

References

1. Ashina M, Hansen JM, Do TP, Melo-Carrillo A, Burstein R, Moskowitz MA (2019) Migraine and the trigeminovascular system-40 years and counting Lancet Neurol 18(8):795-804. https://doi.org/10.1016/s1474-4422(19)30185-1 
2. Karatas H, Erdener SE, Gursoy-Ozdemir Y, Lule S, Eren-Koçak E, Sen ZD, Dalkara T (2013) Spreading depression triggers headache by activating neuronal Panx1 channels. Science. 339(6123):1092-1095. https://doi.org/1 $0.1126 /$ science. 1231897

3. Charles A (2010) Does cortical spreading depression initiate a migraine attack? Maybe not. Headache 50(4):731-733. https://doi.org/10.1111/j.1526-4 610.2010.01646.x

4. Sochocka M, Diniz BS, Leszek J (2017) Inflammatory response in the CNS: friend or foe? Mol Neurobiol 54(10):8071-8089. https://doi.org/10.1007/s12 035-016-0297-1

5. Takizawa T, Shibata M, Kayama Y, Toriumi H, Ebine T, Koh A, Shimizu T, Suzuki N (2016) Temporal profiles of high-mobility group box 1 expression levels after cortical spreading depression in mice. Cephalalgia. 36(1):44-52. https://doi.org/10.1177/0333102415580100

6. Ghaemi A, Sajadian A, Khodaie B, Lotfinia AA, Lotfinia M, Aghabarari A Khaleghi Ghadiri M, Meuth S, Gorji A (2016) Immunomodulatory effect of toll-like receptor-3 ligand poly I:C on cortical spreading depression. Mol Neurobiol 53(1):143-154. https://doi.org/10.1007/s12035-014-8995-z

7. Eising E, Shyti R, t Hoen PAC, Vijfhuizen LS, Huisman SMH, Broos LAM et al (2017) Cortical spreading depression causes unique dysregulation of inflammatory pathways in a transgenic mouse model of migraine. Mo Neurobiol 54(4):2986-2996. https://doi.org/10.1007/s12035-015-9681-5

8. Chen SP, Qin T, Seidel JL, Zheng Y, Eikermann M, Ferrari MD, van den Maagdenberg AMJM, Moskowitz MA, Ayata C, Eikermann-Haerter K (2017) Inhibition of the P2X7-PANX1 complex suppresses spreading depolarization and neuroinflammation. Brain. 140(6):1643-1656. https://doi.org/10.1093/bra in/awx085

9. Ghaemi A, Alizadeh L, Babaei S, Jafarian M, Khaleghi Ghadiri M, Meuth SG, Kovac S, Gorji A (2018) Astrocyte-mediated inflammation in cortical spreading depression. Cephalalgia. 38(4):626-638. https://doi.org/10.1177/ 0333102417702132

10. Bu F, Nie L, Quinn JP, Wang M (2020) Sarcoma family kinase-dependent pannexin-1 activation after cortical spreading depression is mediated by NR2A-containing receptors. Int J Mol Sci 21(4). https://doi.org/10.3390/ ijms21041269

11. Takizawa T, Qin T, Lopes de Morais A, Sugimoto K, Chung JY, Morsett L et al (2020) Non-invasively triggered spreading depolarizations induce a rapid pro-inflammatory response in cerebral cortex. J Cereb Blood Flow Metab 40(5):1117-1131. https://doi.org/10.1177/0271678x19859381

12. Albrecht DS, Mainero C, Ichijo E, Ward N, Granziera C, Zürcher NR, Akeju O, Bonnier G, Price J, Hooker JM, Napadow V, Loggia ML, Hadjikhani N (2019) Imaging of neuroinflammation in migraine with aura: a [(11) C]PBR28 PET/ MRI study. Neurology. 92(17):e2038-e2e50. https://doi.org/10.1212/WNL. 0000000000007371

13. Hadjikhani N, Albrecht DS, Mainero C, Ichijo E, Ward N, Granziera C et al (2020) Extra-axial inflammatory signal in parameninges in migraine with visual aura. Ann Neurol 87(6):939-949 https://doi.org/10.1002/ana.25731

14. Moskowitz MA (1993) Neurogenic inflammation in the pathophysiology and treatment of migraine. Neurology. 43(6 Suppl 3):S16-\$20

15. Levy D (2009) Migraine pain, meningeal inflammation, and mast cells. Curr Pain Headache Rep 13(3):237-240. https://doi.org/10.1007/s11916-009-0040y

16. Levy D, Labastida-Ramirez A, MaassenVanDenBrink A (2018) Current understanding of meningeal and cerebral vascular function underlying migraine headache. Cephalalgia. 39(13):1606-1622. https://doi.org/10.1177/ 0333102418771350

17. Schain AJ, Melo-Carrillo A, Borsook D, Grutzendler J, Strassman AM, Burstein $R$ (2018) Activation of pial and dural macrophages and dendritic cells by cortical spreading depression. Ann Neurol 83(3):508-521. https://doi.org/1 0.1002/ana.25169

18. Burstein R, Noseda R, Borsook D (2015) Migraine: multiple processes, complex pathophysiology. J Neurosci 35(17):6619-6629. https://doi.org/10.1 523/jneurosci.0373-15.2015

19. Edvinsson L, Haanes KA (2021) Identifying new antimigraine targets: lessons from molecular biology. Trends Pharmacol Sci 42(4):217-225. https://doi. org/10.1016/j.tips.2021.01.002

20. Ji RR, Nackley A, Huh Y, Terrando N, Maixner W (2018) Neuroinflammation and central sensitization in chronic and widespread pain. Anesthesiology. 129(2):343-366. https://doi.org/10.1097/ALN.0000000000002130

21. Frederiksen SD, Haanes KA, Warfvinge K, Edvinsson L (2017) Perivascular neurotransmitters: regulation of cerebral blood flow and role in primary headaches. J Cereb Blood Flow Metab 39(4):610-632. https://doi.org/10.11 77/0271678X17747188

22. Waschek JA, Baca SM, Akerman S (2018) PACAP and migraine headache: immunomodulation of neural circuits in autonomic ganglia and brain parenchyma. J Headache Pain 19(1):23. https://doi.org/10.1186/s10194-0180850-6

23. Bolay H, Reuter U, Dunn AK, Huang Z, Boas DA, Moskowitz MA (2002) Intrinsic brain activity triggers trigeminal meningeal afferents in a migraine model. Nat Med 8(2):136-142. https://doi.org/10.1038/nm0202-136

24. Schain AJ, Melo-Carrillo A, Stratton J, Strassman AM, Burstein R (2019) CSDinduced arterial dilatation and plasma protein extravasation are unaffected by Fremanezumab: implications for CGRP's role in migraine with aura. J Neurosci 39(30):6001-6011. https://doi.org/10.1523/jneurosci.0232-19.2019

25. Nagata E, Moriguchi H, Takizawa S, Horie T, Yanagimachi N, Takagi S (2009) The middle meningial artery during a migraine attack: 3T magnetic resonance angiography study. Intern Med 48(24):2133-2135. https://doi. org/10.2169/internalmedicine.48.2565

26. Amin FM, Asghar MS, Hougaard A, Hansen AE, Larsen VA, de Koning PJ et al (2013) Magnetic resonance angiography of intracranial and extracranial arteries in patients with spontaneous migraine without aura: a crosssectional study. Lancet Neurol 12(5):454-461. https://doi.org/10.1016/s14 74-4422(13)70067-x

27. Khan S, Amin FM, Christensen CE, Ghanizada H, Younis S, Olinger ACR, de Koning PJH, Larsson HBW, Ashina M (2018) Meningeal contribution to migraine pain: a magnetic resonance angiography study. Brain. 142(1):93102. https://doi.org/10.1093/brain/awy300

28. Asghar MS, Hansen AE, Amin FM, van der Geest RJ, Koning P, Larsson HB et al (2011) Evidence for a vascular factor in migraine. Ann Neurol 69(4): 635-645. https://doi.org/10.1002/ana.22292

29. Melo-Carrillo A, Strassman AM, Nir RR, Schain AJ, Noseda R, Stratton J, Burstein R (2017) Fremanezumab-a humanized monoclonal anti-CGRP antibody-inhibits thinly myelinated (A $\delta$ ) but not unmyelinated (C) meningeal nociceptors. J Neurosci 37(44):10587-10596. https://doi.org/10.1 523/jneurosci.2211-17.2017

30. Goadsby PJ, Edvinsson L, Ekman R (1990) Vasoactive peptide release in the extracerebral circulation of humans during migraine headache. Ann Neurol 28(2):183-187. https://doi.org/10.1002/ana.410280213

31. Hansen JM, Hauge AW, Olesen J, Ashina M (2010) Calcitonin gene-related peptide triggers migraine-like attacks in patients with migraine with aura. Cephalalgia. 30(10):1179-1186. https://doi.org/10.1177/0333102410368444

32. Charles A, Pozo-Rosich P (2019) Targeting calcitonin gene-related peptide: a new era in migraine therapy. Lancet. 394(10210):1765-1774. https://doi. org/10.1016/s0140-6736(19)32504-8

33. Zhang XC, Strassman AM, Burstein R, Levy D (2007) Sensitization and activation of intracranial meningeal nociceptors by mast cell mediators. J Pharmacol Exp Ther 322(2):806-812. https://doi.org/10.1124/jpet.107.123745

34. Zhou Q, Wang YW, Ni PF, Chen YN, Dong HQ, Qian YN (2018) Effect of tryptase on mouse brain microvascular endothelial cells via proteaseactivated receptor 2. J Neuroinflammation 15(1):248. https://doi.org/10.1186/ s12974-018-1287-1

35. Hassler SN, Ahmad FB, Burgos-Vega CC, Boitano S, Vagner J, Price TJ, Dussor G (2019) Protease activated receptor 2 (PAR2) activation causes migrainelike pain behaviors in mice. Cephalalgia. 39(1):111-122. https://doi.org/10.11 77/0333102418779548

36. Kopruszinski CM, Thornton P, Arnold J, Newton P, Lowne D, Navratilova E, Swiokla J, Dodick DW, Dobson C, Gurrell I, Chessell IP, Porreca F (2020) Characterization and preclinical evaluation of a protease activated receptor 2 (PAR2) monoclonal antibody as a preventive therapy for migraine. Cephalalgia. 40(14):1535-1550. https://doi.org/10.1177/0333102420966581

37. Nurkhametova D, Kudryavtsev I, Guselnikova V, Serebryakova M, Giniatullina RR, Wojciechowski S, Tore F, Rizvanov A, Koistinaho J, Malm T, Giniatullin R (2019) Activation of P2X7 receptors in peritoneal and meningeal mast cells detected by uptake of organic dyes: possible purinergic triggers of neuroinflammation in meninges. Front Cell Neurosci 13:45. https://doi.org/1 0.3389/fncel.2019.00045

38. Koroleva K, Gafurov O, Guselnikova V, Nurkhametova D, Giniatullina R, Sitdikova G, Mattila OS, Lindsberg PJ, Malm TM, Giniatullin R (2019) Meningeal mast cells contribute to ATP-induced nociceptive firing in trigeminal nerve terminals: direct and indirect purinergic mechanisms triggering migraine pain. Front Cell Neurosci 13:195. https://doi.org/10.3389/ fncel.2019.00195 
39. Pedersen SH, Ramachandran R, Amrutkar DV, Petersen S, Olesen J, JansenOlesen I (2015) Mechanisms of glyceryl trinitrate provoked mast cell degranulation. Cephalalgia. 35(14):1287-1297. https://doi.org/10.1177/03331 02415574846

40. Jansen-Olesen I, Hougaard PS (2018) PACAP and its receptors in cranial arteries and mast cells. J Headache Pain 19(1):16. https://doi.org/10.1186/s1 0194-017-0822-2

41. Kulka M, Sheen CH, Tancowny BP, Grammer LC, Schleimer RP (2008) Neuropeptides activate human mast cell degranulation and chemokine production. Immunology. 123(3):398-410. https://doi.org/10.1111/j.1365-2 567.2007.02705.x

42. Eftekhari S, Warfvinge K, Blixt FW, Edvinsson L (2013) Differentiation of nerve fibers storing CGRP and CGRP receptors in the peripheral trigeminovascular system. J Pain 14(11):1289-1303. https://doi.org/10.1016/j.jpain.2013.03.010

43. Assas BM, Pennock JI, Miyan JA (2014) Calcitonin gene-related peptide is a key neurotransmitter in the neuro-immune axis. Front Neurosci 8:23. https:// doi.org/10.3389/fnins.2014.00023

44. Carucci JA, Ignatius R, Wei Y, Cypess AM, Schaer DA, Pope M, Steinman RM, Mojsov S (2000) Calcitonin gene-related peptide decreases expression of HLA-DR and CD86 by human dendritic cells and dampens dendritic celldriven $T$ cell-proliferative responses via the type I calcitonin gene-related peptide receptor. J Immunol 164(7):3494-3499. https://doi.org/10.4049/ jimmunol.164.7.3494

45. Khan S, Amin FM, Fliedner FP, Christensen CE, Tolnai D, Younis S, Olinger ACR, Birgens H, Daldrup-Link H, Kjær A, Larsson HBW, Lindberg U, Ashina M (2019) Investigating macrophage-mediated inflammation in migraine using ultrasmall superparamagnetic iron oxide-enhanced 3T magnetic resonance imaging. Cephalalgia. 39(11):1407-1420. https://doi.org/10.1177/033310241 9848122

46. Buzzi MG, Carter WB, Shimizu T, Heath H 3rd, Moskowitz MA (1991) Dihydroergotamine and sumatriptan attenuate levels of CGRP in plasma in rat superior sagittal sinus during electrical stimulation of the trigeminal ganglion. Neuropharmacology. 30(11):1193-1200. https://doi.org/10.1016/ 0028-3908(91)90165-8

47. Edvinsson L, Haanes KA, Warfvinge K, Krause DN (2018) CGRP as the target of new migraine therapies - successful translation from bench to clinic. Nat Rev Neurol 14(6):338-350. https://doi.org/10.1038/s41582-018-0003-1

48. Rubio-Beltrán E, Labastida-Ramírez A, Villalón CM, MaassenVanDenBrink A (2018) Is selective 5-HT (1F) receptor agonism an entity apart from that of the triptans in antimigraine therapy? Pharmacol Ther 186:88-97. https://doi. org/10.1016/j.pharmthera.2018.01.005

49. Goldstein DJ, Offen WW, Klein EG, Phebus LA, Hipskind P, Johnson KW, Ryan RE Jr (2001) Lanepitant, an NK-1 antagonist, in migraine prevention. Cephalalgia. 21(2):102-106. https://doi.org/10.1046/j.1468-2982.2001.00161.x

50. Goldstein DJ, Wang O, Saper JR, Stoltz R, Silberstein SD, Mathew NT (1997) Ineffectiveness of neurokinin-1 antagonist in acute migraine: a crossover study. Cephalalgia. 17(7):785-790. https://doi.org/10.1046/j.1468-2982.1997.1 707785.x

51. Roon Kl, Olesen J, Diener HC, Ellis P, Hettiarachchi J, Poole PH, Christianssen I, Kleinermans D, Kok JG, Ferrari MD (2000) No acute antimigraine efficacy of CP-122,288, a highly potent inhibitor of neurogenic inflammation: results of two randomized, double-blind, placebo-controlled clinical trials. Ann Neurol 47(2):238-241. https://doi.org/10.1002/1531-8249(200002)47:2<238::AID-A NA15>3.0.CO:2-L

52. Earl NL, McDonald SA, Lowy MT (1999) The 4991 W93 Investigator Group. Efficacy and tolerability of the neurogenic inflammation inhibitor, 4991W93, in the acute treatment of migraine. Cephalalgia. 19:357

53. Rosenberg JH, Silberstein SD (2005) The headache of SAH responds to sumatriptan. Headache. 45(5):597-598. https://doi.org/10.1111/j.1526-4610.2 005.05114.x

54. Hoffmann O, Keilwerth N, Bille MB, Reuter U, Angstwurm K, Schumann RR, Dirnagl U, Weber JR (2002) Triptans reduce the inflammatory response in bacterial meningitis. J Cereb Blood Flow Metab 22(8):988-996. https://doi. org/10.1097/00004647-200208000-00010

55. Wiesmann M, Koedel U, Brückmann H, Pfister HW (2002) Experimental bacterial meningitis in rats: demonstration of hydrocephalus and meningeal enhancement by magnetic resonance imaging. Neurol Res 24(3):307-310. https://doi.org/10.1179/016164102101199792

56. Buzzi MG, Moskowitz MA (2005) The pathophysiology of migraine: year 2005. J Headache Pain 6(3):105-111. https://doi.org/10.1007/s10194-005-01 65-2
57. Lindner A, Reiners K, Toyka KV (1996) Meningeal hyperperfusion visualized by MRI in a patient with visual hallucinations and migraine. Headache. 36(1): 53-57. https://doi.org/10.1046/j.1526-4610.1996.3601053.x

58. Smith M, Cros D, Sheen V (2002) Hyperperfusion with vasogenic leakage by fMRI in migraine with prolonged aura. Neurology. 58(8):1308-1310. https:// doi.org/10.1212/wnl.58.8.1308-a

59. Dreier JP, Jurkat-Rott K, Petzold GC, Tomkins O, Klingebiel R, Kopp UA, Lehmann-Horn F, Friedman A, Dichgans M (2005) Opening of the bloodbrain barrier preceding cortical edema in a severe attack of FHM type II. Neurology. 64(12):2145-2147. https://doi.org/10.1212/01.Wnl.0000176298.63 840.99

60. Levy D (2010) Migraine pain and nociceptor activation--where do we stand? Headache. 50(5):909-916. https://doi.org/10.1111/j.1526-4610.2010.01670.x

61. Olesen J, Burstein R, Ashina M, Tfelt-Hansen P (2009) Origin of pain in migraine: evidence for peripheral sensitisation. Lancet Neurol 8(7):679-690. https://doi.org/10.1016/s1474-4422(09)70090-0

62. Nassini R, Materazzi S, Vriens J, Prenen J, Benemei S, De Siena G et al (2012) The 'headache tree' via umbellulone and TRPA1 activates the trigeminovascular system. Brain. 135(Pt 2):376-390. https://doi.org/10.1093/ brain/awr272

63. Reuter U, Bolay H, Jansen-Olesen I, Chiarugi A, Sanchez del Rio M, Letourneau $R$ et al (2001) Delayed inflammation in rat meninges: implications for migraine pathophysiology. Brain. 124(Pt 12):2490-2502. https://doi.org/10.1093/brain/124.12.2490

64. Christiansen I, Daugaard D, Lykke Thomsen L, Olesen J (2000) Glyceryl trinitrate induced headache in migraineurs - relation to attack frequency. Eur J Neurol 7(4):405-411. https://doi.org/10.1046/j.1468-1331.2000.00094.x

65. Thomsen LL, Kruuse C, Iversen HK, Olesen J (1994) A nitric oxide donor (nitroglycerin) triggers genuine migraine attacks. Eur J Neurol 1(1):73-80. https://doi.org/10.1111/j.1468-1331.1994.tb00053.x

66. Karsan N, Goadsby PJ (2018) Biological insights from the premonitory symptoms of migraine. Nat Rev Neurol 14(12):699-710. https://doi.org/10.1 038/s41582-018-0098-4

67. Weiller C, May A, Limmroth V, Jüptner M, Kaube H, Schayck RV, Coenen HH, Dlener HC (1995) Brain stem activation in spontaneous human migraine attacks. Nat Med 1(7):658-660. https://doi.org/10.1038/nm0795-658

68. Bahra A, Matharu MS, Buchel C, Frackowiak RS, Goadsby PJ (2001) Brainstem activation specific to migraine headache. Lancet. 357(9261):1016-1017. https://doi.org/10.1016/s0140-6736(00)04250-1

69. Knight YE, Goadsby PJ (2001) The periaqueductal grey matter modulates trigeminovascular input: a role in migraine? Neuroscience. 106(4):793-800. https://doi.org/10.1016/s0306-4522(01)00303-7

70. Afridi SK, Giffin NJ, Kaube H, Friston KJ, Ward NS, Frackowiak RS et al (2005) A positron emission tomographic study in spontaneous migraine. Arch Neurol 62(8):1270-1275. https://doi.org/10.1001/archneur.62.8.1270

71. Afridi SK, Matharu MS, Lee L, Kaube H, Friston KJ, Frackowiak RS et al (2005) A PET study exploring the laterality of brainstem activation in migraine using glyceryl trinitrate. Brain. 128(Pt 4):932-939. https://doi.org/10.1093/bra in/awh416

72. Jeong HJ, Chenu D, Johnson EE, Connor M, Vaughan CW (2008) Sumatriptan inhibits synaptic transmission in the rat midbrain periaqueductal grey. Mol Pain 4:54. https://doi.org/10.1186/1744-8069-4-54

73. Raskin NH, Hosobuchi Y, Lamb S (1987) Headache may arise from perturbation of brain. Headache. 27(8):416-420. https://doi.org/10.1111/j.152 6-4610.1987.hed2708416.x

74. Sprenger T, Borsook D (2012) Migraine changes the brain: neuroimaging makes its mark. Curr Opin Neurol 25(3):252-262. https://doi.org/10.1097/ WCO.0b013e3283532ca3

75. Borsook D, Burstein R (2012) The enigma of the dorsolateral pons as a migraine generator. Cephalalgia. 32(11):803-812. https://doi.org/10.1177/ 0333102412453952

76. Denuelle M, Fabre N, Payoux P, Chollet F, Geraud G (2007) Hypothalamic activation in spontaneous migraine attacks. Headache. 47(10):1418-1426. https://doi.org/10.1111/j.1526-4610.2007.00776.x

77. Maniyar FH, Sprenger T, Monteith T, Schankin C, Goadsby PJ (2014) Brain activations in the premonitory phase of nitroglycerin-triggered migraine attacks. Brain. 137(Pt 1):232-241. https://doi.org/10.1093/brain/a wt320

78. Schulte LH, May A (2016) The migraine generator revisited: continuous scanning of the migraine cycle over 30 days and three spontaneous attacks. Brain. 139(Pt 7):1987-1993. https://doi.org/10.1093/brain/aww097 
79. Meylakh N, Marciszewski KK, Di Pietro F, Macefield VG, Macey PM, Henderson LA (2018) Deep in the brain: changes in subcortical function immediately preceding a migraine attack. Hum Brain Mapp 39(6):26512663. https://doi.org/10.1002/hbm.24030

80. Moskowitz MA, Nozaki K, Kraig RP (1993) Neocortical spreading depression provokes the expression of c-fos protein-like immunoreactivity within trigeminal nucleus caudalis via trigeminovascular mechanisms. J Neurosci 13(3):1167-1177. https://doi. org/10.1523/JNEUROSCI.13-03-01167.1993

81. Pietrobon D, Moskowitz MA (2014) Chaos and commotion in the wake of cortical spreading depression and spreading depolarizations. Nat Rev Neurosci 15(6):379-393. https://doi.org/10.1038/nrn3770

82. Hadjikhani N, Sanchez Del Rio M, Wu O, Schwartz D, Bakker D, Fischl B et al (2001) Mechanisms of migraine aura revealed by functional MRI in human visual cortex. Proc Natl Acad Sci U S A 98(8):4687-4692. https://doi.org/10.1 073/pnas.071582498

83. Zhang X, Levy D, Noseda R, Kainz V, Jakubowski M, Burstein R (2010) Activation of meningeal nociceptors by cortical spreading depression: implications for migraine with aura. J Neurosci 30(26):8807-8814. https://doi. org/10.1523/jneurosci.0511-10.2010

84. Zhang X, Levy D, Kainz V, Noseda R, Jakubowski M, Burstein R (2011) Activation of central trigeminovascular neurons by cortical spreading depression. Ann Neurol 69(5):855-865. https://doi.org/10.1002/ana.22329

85. Zhao J, Levy D (2015) Modulation of intracranial meningeal nociceptor activity by cortical spreading depression: a reassessment. J Neurophysiol 113(7):2778-2785. https://doi.org/10.1152/jn.00991.2014

86. Zhao J, Levy D (2016) Cortical spreading depression promotes persistent mechanical sensitization of intracranial meningeal afferents: implications for the intracranial mechanosensitivity of migraine. eNeuro 3(6). https://doi. org/10.1523/eneuro.0287-16.2016

87. Zhao J, Levy D (2018) The CGRP receptor antagonist BIBN4096 inhibits prolonged meningeal afferent activation evoked by brief local $\mathrm{K}(+)$ stimulation but not cortical spreading depression-induced afferent sensitization. Pain Rep 3(1):e632. https://doi.org/10.1097/pr9. 0000000000000632

88. Arngrim N, Hougaard A, Ahmadi K, Vestergaard MB, Schytz HW, Amin FM, Larsson HBW, Olesen J, Hoffmann MB, Ashina M (2017) Heterogenous migraine aura symptoms correlate with visual cortex functional magnetic resonance imaging responses. Ann Neurol 82(6):925-939. https://doi.org/1 0.1002/ana.25096

89. Dalkara T, Nozari A, Moskowitz MA (2010) Migraine aura pathophysiology: the role of blood vessels and microembolisation. Lancet Neurol 9(3):309317. https://doi.org/10.1016/S1474-4422(09)70358-8

90. Stam AH, Haan J, van den Maagdenberg AM, Ferrari MD, Terwindt GM (2009) Migraine and genetic and acquired vasculopathies. Cephalalgia. 29(9):1006-1017. https://doi.org/10.1111/j.1468-2982.2009.01940.x

91. Knotkova H, Pappagallo M (2007) Imaging intracranial plasma extravasation in a migraine patient: a case report. Pain Med 8(4):383-387. https://doi.org/1 0.1111/j.1526-4637.2006.00197.x

92. Herisson F, Frodermann V, Courties G, Rohde D, Sun Y, Vandoorne K, Wojtkiewicz GR, Masson GS, Vinegoni C, Kim J, Kim DE, Weissleder R, Swirski FK, Moskowitz MA, Nahrendorf M (2018) Direct vascular channels connect skull bone marrow and the brain surface enabling myeloid cell migration. Nat Neurosci 21(9):1209-1217. https://doi.org/10.1038/s41593018-0213-2

93. Kissoon NR, Cutrer FM (2017) Aura and other neurologic dysfunction in or with migraine. Headache 57(7):1179-1194 https://doi.org/10.1111/head.13101

94. Purdy RA (2008) Migraine with and without aura share the same pathogenic mechanisms. Neurol Sci 29(Suppl 1):S44-S46. https://doi.org/1 0.1007/s10072-008-0885-6

95. Kilic K, Karatas H, Dönmez-Demir B, Eren-Kocak E, Gursoy-Ozdemir Y, Can A, Petit JM, Magistretti PJ, Dalkara T (2018) Inadequate brain glycogen or sleep increases spreading depression susceptibility. Ann Neurol 83(1):61-73. https://doi.org/10.1002/ana.25122

96. Petit JM, Eren-Koçak E, Karatas H, Magistretti P, Dalkara T (2021) Brain glycogen metabolism: a possible link between sleep disturbances, headache and depression. Sleep Med Rev 59:101449. https://doi.org/10.101 6/j.smrv.2021.101449

97. Dalkara T, Kiliç K (2013) How does fasting trigger migraine? A hypothesis. Curr Pain Headache Rep 17(10):368. https://doi.org/10.1007/s11916-013-03 68-1
98. Gross EC, Lisicki M, Fischer D, Sándor PS, Schoenen J (2019) The metabolic face of migraine - from pathophysiology to treatment. Nat Rev Neurol 15(11):627-643. https://doi.org/10.1038/s41582-019-0255-4

99. Borkum JM (2021) Brain energy deficit as a source of oxidative stress in migraine: a molecular basis for migraine susceptibility. Neurochem Res 46(8):1913-1932. https://doi.org/10.1007/s11064-021-03335-9

100. Mercier F, Hatton Gl (2000) Immunocytochemical basis for a meningeo-glial network. J Comp Neurol 420(4):445-465. https://doi.org/10.1002/(sici)10969861(20000515)420:4<445::aid-cne4>3.0.co;2-3

101. Koroleva VI, Bures J (1993) Rats do not experience cortical or hippocampal spreading depression as aversive. Neurosci Lett 149(2):153-156. https://doi. org/10.1016/0304-3940(93)90759-e

102. Akcali D, Sayin A, Sara Y, Bolay H (2010) Does single cortical spreading depression elicit pain behaviour in freely moving rats? Cephalalgia. 30(10): 1195-1206. https://doi.org/10.1177/0333102409360828

103. Houben T, Loonen IC, Baca SM, Schenke M, Meijer JH, Ferrari MD et al (2017) Optogenetic induction of cortical spreading depression in anesthetized and freely behaving mice. J Cereb Blood Flow Metab 37(5): 1641-1655. https://doi.org/10.1177/0271678x16645113

104. Harriott AM, Chung DY, Uner A, Bozdayi RO, Morais A, Takizawa T, Qin T, Ayata C (2021) Optogenetic spreading depression elicits trigeminal pain and anxiety behavior. Ann Neurol 89(1):99-110. https://doi.org/10.1002/ana.2592 6

105. Grinberg YY, Milton JG, Kraig RP (2011) Spreading depression sends microglia on Lévy flights. PLoS One 6(4):e19294. https://doi.org/10.1371/ journal.pone.0019294

106. Shibata M, Suzuki N (2017) Exploring the role of microglia in cortical spreading depression in neurological disease. J Cereb Blood Flow Metab 37(4):1182-1191. https://doi.org/10.1177/0271678X17690537

107. Cao Y, Aurora SK, Nagesh V, Patel SC, Welch KM (2002) Functional MRIBOLD of brainstem structures during visually triggered migraine. Neurology. 59(1):72-78. https://doi.org/10.1212/wnl.59.1.72

108. Cao Y, Welch KM, Aurora S, Vikingstad EM (1999) Functional MRI-BOLD of visually triggered headache in patients with migraine. Arch Neurol 56(5): 548-554. https://doi.org/10.1001/archneur.56.5.548

109. Sanchez del Rio M, Bakker D, Wu O, Agosti R, Mitsikostas DD, Ostergaard L et al (1999) Perfusion weighted imaging during migraine: spontaneous visual aura and headache. Cephalalgia. 19(8):701-707. https://doi.org/10.104 6/j.1468-2982.1999.019008701.x

110. Woods RP, lacoboni M, Mazziotta JC (1994) Brief report: bilateral spreading cerebral hypoperfusion during spontaneous migraine headache. N Engl J Med 331(25):1689-1692. https://doi.org/10.1056/NEJM199412223312505

111. Dahlem MA, Schmidt B, Bojak I, Boie S, Kneer F, Hadjikhani N et al (2015) Cortical hot spots and labyrinths: why cortical neuromodulation for episodic migraine with aura should be personalized. Front Comput Neurosci 9(29). https://doi.org/10.3389/fncom.2015.00029

112. Cutrer FM, Sorensen AG, Weisskoff RM, Ostergaard L, Sanchez del Rio M, Lee EJ et al (1998) Perfusion-weighted imaging defects during spontaneous migrainous aura. Ann Neurol 43(1):25-31. https://doi.org/10.1002/ana.41043 0108

113. Peng KP, May A (2019) Migraine understood as a sensory threshold disease. Pain. 160(7):1494-1501. https://doi.org/10.1097/j.pain.0000000000001531

114. Stankewitz A, Aderjan D, Eippert F, May A (2011) Trigeminal nociceptive transmission in migraineurs predicts migraine attacks. J Neurosci 31(6):19371943. https://doi.org/10.1523/JNEUROSCI.4496-10.2011

115. Ray A, Zoidl G, Weickert S, Wahle P, Dermietzel R (2005) Site-specific and developmental expression of pannexin1 in the mouse nervous system. Eur J Neurosci 21(12):3277-3290. https://doi.org/10.1111/j.1460-9568.2005.04139.x

116. Zoidl G, Petrasch-Parwez E, Ray A, Meier C, Bunse S, Habbes HW, Dahl G, Dermietzel R (2007) Localization of the pannexin 1 protein at postsynaptic sites in the cerebral cortex and hippocampus. Neuroscience. 146(1):9-16. https://doi.org/10.1016/j.neuroscience.2007.01.061

117. Thompson RJ, Macvicar BA (2008) Connexin and pannexin hemichannels of neurons and astrocytes. Channels (Austin) 2(2):81-86. https://doi.org/10.41 61/chan.2.2.6003

118. Sarrouilhe D, Dejean C, Mesnil M (2017) Connexin43- and pannexin-based channels in neuroinflammation and cerebral neuropathies. Front Mol Neurosci 10:320. https://doi.org/10.3389/fnmol.2017.00320

119. Makarenkova HP, Shah SB, Shestopalov VI (2018) The two faces of pannexins: new roles in inflammation and repair. J Inflamm Res 11:273-288. https://doi.org/10.2147/jir.S128401 
120. Bialecki J, Werner A, Weilinger NL, Tucker CM, Vecchiarelli HA, Egaña J, Mendizabal-Zubiaga J, Grandes P, Hill MN, Thompson RJ (2020) Suppression of presynaptic glutamate release by postsynaptic metabotropic NMDA receptor signalling to pannexin-1. J Neurosci 40(4):729-742. https://doi.org/1 0.1523/jneurosci.0257-19.2019

121. Thompson RJ, Jackson MF, Olah ME, Rungta RL, Hines DJ, Beazely MA MacDonald JF, MacVicar BA (2008) Activation of pannexin-1 hemichannels augments aberrant bursting in the hippocampus. Science. 322(5907):15551559. https://doi.org/10.1126/science.1165209

122. MacVicar BA, Thompson RJ (2010) Non-junction functions of pannexin-1 channels. Trends Neurosci 33(2):93-102. https://doi.org/10.1016/j.tins.2 009.11 .007

123. Sandilos JK, Chiu YH, Chekeni FB, Armstrong AJ, Walk SF, Ravichandran KS, Bayliss DA (2012) Pannexin 1, an ATP release channel, is activated by caspase cleavage of its pore-associated C-terminal autoinhibitory region. $J$ Biol Chem 287(14):11303-11311. https://doi.org/10.1074/jbc.M111.323378

124. Chekeni FB, Elliott MR, Sandilos JK, Walk SF, Kinchen JM, Lazarowski ER, Armstrong AJ, Penuela S, Laird DW, Salvesen GS, Isakson BE, Bayliss DA, Ravichandran KS (2010) Pannexin 1 channels mediate 'find-me' signal release and membrane permeability during apoptosis. Nature. 467(7317): 863-867. https://doi.org/10.1038/nature09413

125. Silverman WR, de Rivero Vaccari JP, Locovei S, Qiu F, Carlsson SK, Scemes E, Keane RW, Dahl G (2009) The pannexin 1 channel activates the inflammasome in neurons and astrocytes. J Biol Chem 284(27):18143-18151. https://doi.org/10.1074/jbc.M109.004804

126. Weilinger NL, Tang PL, Thompson RJ (2012) Anoxia-induced NMDA receptor activation opens pannexin channels via Src family kinases. J Neurosci 32(36): 12579-12588. https://doi.org/10.1523/jneurosci.1267-12.2012

127. Bao L, Locovei S, Dahl G (2004) Pannexin membrane channels are mechanosensitive conduits for ATP. FEBS Lett 572(1):65-68 https://doi.org/1 0.1016/j.febslet.2004.07.009

128. Wang J, Ambrosi C, Qiu F, Jackson DG, Sosinsky G, Dahl G (2014) The membrane protein Pannexin1 forms two open-channel conformations depending on the mode of activation. Sci Signal 7(335):ra69. https://doi. org/10.1126/scisignal.2005431

129. Yeung AK, Patil CS, Jackson MF (2020) Pannexin-1 in the CNS: emerging concepts in health and disease. J Neurochem 154(5):468-485. https://doi. org/10.1111/jnc.15004

130. Beamer E, Gölöncsér F, Horváth G, Bekő K, Otrokocsi L, Koványi B, Sperlágh B (2016) Purinergic mechanisms in neuroinflammation: an update from molecules to behavior. Neuropharmacology. 104:94-104. https://doi.org/1 0.1016/j.neuropharm.2015.09.019

131. Savio LEB, de Andrade MP, da Silva CG, Coutinho-Silva R (2018) The P2X7 receptor in inflammatory diseases: angel or demon? Front Pharmacol 9:52. https://doi.org/10.3389/fphar.2018.00052

132. Di Virgilio F, Giuliani AL, Vultaggio-Poma V, Falzoni S, Sarti AC (2018) Nonnucleotide agonists triggering $\mathrm{P} 2 \mathrm{X} 7$ receptor activation and pore formation. Front Pharmacol 9:39. https://doi.org/10.3389/fphar.2018.00039

133. Locovei S, Wang J, Dahl G (2006) Activation of pannexin 1 channels by ATP through P2Y receptors and by cytoplasmic calcium. FEBS Lett 580(1):239244. https://doi.org/10.1016/j.febslet.2005.12.004

134. Pelegrin P, Surprenant A (2006) Pannexin-1 mediates large pore formation and interleukin-1 beta release by the ATP-gated P2X7 receptor. EMBO J 25(21):5071-5082. https://doi.org/10.1038/sj.emboj.7601378

135. Illes P, Khan TM, Rubini P (2017) Neuronal P2X7 receptors revisited: do they really exist? J Neurosci 37(30):7049-7062. https://doi.org/10.1523/ jneurosci.3103-16.2017

136. Kaczmarek-Hajek K, Zhang J, Kopp R, Grosche A, Rissiek B, Saul A, Bruzzone $S$, Engel T, Jooss T, Krautloher A, Schuster S, Magnus T, Stadelmann C, Sirko S, Koch-Nolte F, Eulenburg V, Nicke A (2018) Re-evaluation of neuronal P2X7 expression using novel mouse models and a P2X7-specific nanobody. Elife. 7. https://doi.org/10.7554/eLife.36217

137. Andrejew R, Oliveira-Giacomelli Á, Ribeiro DE, Glaser T, Arnaud-Sampaio VF, Lameu C, Ulrich H (2020) The P2X7 receptor: central hub of brain diseases. Front Mol Neurosci 13:124. https://doi.org/10.3389/fnmol.2020.00124

138. Zhao YF, Tang Y, Illes P (2021) Astrocytic and oligodendrocytic P2X7 receptors determine neuronal functions in the CNS. Front Mol Neurosci 14: 641570. https://doi.org/10.3389/fnmol.2021.641570

139. Chun BJ, Stewart BD, Vaughan DD, Bachstetter AD, Kekenes-Huskey PM (2019) Simulation of P2X-mediated calcium signalling in microglia. J Physiol 597(3):799-818. https://doi.org/10.1113/jp277377
140. Navis KE, Fan CY, Trang T, Thompson RJ, Derksen DJ (2020) Pannexin 1 channels as a therapeutic target: structure, inhibition, and outlook. ACS Chem Neurosci 11(15):2163-2172. https://doi.org/10.1021/acschemneuro. 0c00333

141. Lamkanfi M, Dixit VM (2014) Mechanisms and functions of inflammasomes. Cell. 157(5):1013-1022. https://doi.org/10.1016/j.cell.2014.04.007

142. Caseley EA, Poulter JA, Rodrigues F, Caseley EA, Poulter JA, McDermott MF et al (2020) Inflammasome inhibition under physiological and pharmacologicalconditions. Genes Immun 21(4):211-223. https://doi.org/1 0.1038/s41435-020-0104-x

143. Vande Walle L, Kanneganti TD, Lamkanfi M (2011) HMGB1 release by inflammasomes. Virulence. 2(2):162-165. https://doi.org/10.4161/viru.2.2.154 80

144. Lu B, Wang H, Andersson U, Tracey KJ (2013) Regulation of HMGB1 release by inflammasomes. Protein Cell 4(3):163-167. https://doi.org/10.1007/s1323 8-012-2118-2

145. Liu HD, Li W, Chen ZR, Hu YC, Zhang DD, Shen W, Zhou ML, Zhu L, Hang $\mathrm{CH}$ (2013) Expression of the NLRP3 inflammasome in cerebral cortex after traumatic brain injury in a rat model. Neurochem Res 38(10):2072-2083. https://doi.org/10.1007/s11064-013-1115-Z

146. Song L, Pei L, Yao S, Wu Y, Shang Y (2017) NLRP3 inflammasome in neurological diseases, from functions to therapies. Front Cell Neurosci 11:63. https://doi.org/10.3389/fncel.2017.00063

147. Kitley JL, Lachmann HJ, Pinto A, Ginsberg L (2010) Neurologic manifestations of the cryopyrin-associated periodic syndrome. Neurology. 74(16):1267-1270. https://doi.org/10.1212/WNL.0b013e3181d9ed69

148. Miyamae T (2012) Cryopyrin-associated periodic syndromes: diagnosis and management. Paediatr Drugs 14(2):109-117. https://doi.org/10.2165/11 595040-000000000-00000

149. Keddie S, Parker T, Lachmann HJ, Ginsberg L (2018) Cryopyrin-associated periodic fever syndrome and the nervous system. Curr Treat Options Neurol 20(10):43. https://doi.org/10.1007/s11940-018-0526-1

150. Sarchielli P, Alberti A, Codini M, Floridi A, Gallai V (2000) Nitric oxide metabolites, prostaglandins and trigeminal vasoactive peptides in internal jugular vein blood during spontaneous migraine attacks. Cephalalgia. 20(10):907-918. https://doi.org/10.1046/j.1468-2982.2000.00146x

151. Sarchielli P, Alberti A, Vaianella L, Pierguidi L, Floridi A, Mazzotta G, Floridi A, Gallai V (2004) Chemokine levels in the jugular venous blood of migraine without aura patients during attacks. Headache. 44(10):961-968. https://doi. org/10.1111/j.1526-4610.2004.04189.x

152. Sarchielli P, Alberti A, Baldi A, Coppola F, Rossi C, Pierguidi L et al (2006) Proinflammatory cytokines, adhesion molecules, and lymphocyte integrin expression in the internal jugular blood of migraine patients without aura assessed ictally. Headache 46(2):200-207 https://doi.org/10.1111/j.1526-461 0.2006.00337.x

153. Stros M (2010) HMGB proteins: interactions with DNA and chromatin. Biochim Biophys Acta 1799(1-2):101-113. https://doi.org/10.1016/j.bbagrm.2 009.09.008

154. Bianchi ME (2007) DAMPs, PAMPs and alarmins: all we need to know about danger. J Leukoc Biol 81(1):1-5. https://doi.org/10.1189/jlb.0306164

155. Andersson U, Tracey KJ (2011) HMGB1 is a therapeutic target for sterile inflammation and infection. Annu Rev Immunol 29(1):139-162. https://doi. org/10.1146/annurev-immunol-030409-101323

156. Bertheloot D, Latz E (2017) HMGB1, IL-1a, IL-33 and S100 proteins: dualfunction alarmins. Cell Mol Immunol 14(1):43-64. https://doi.org/10.1038/ cmi.2016.34

157. Paudel YN, Angelopoulou E, Piperi C, Balasubramaniam VRMT, Othman I, Shaikh MF (2019) Enlightening the role of high mobility group box 1 (HMGB1) in inflammation: updates on receptor signalling. Eur J Pharmacol 858:172487 https://doi.org/10.1016/j.ejphar.2019.172487

158. Dehghani A, Phisonkunkasem T, Yilmaz Ozcan S, Dalkara T, van den Maagdenberg A, Tolner EA et al (2021) Widespread brain parenchymal HMGB1 and NF-KB neuroinflammatory responses upon cortical spreading depolarization in familial hemiplegic migraine type 1 mice. Neurobiol Dis 156:105424. https://doi.org/10.1016/j.nbd.2021.105424

159. Kaya Z (2019) Resolution of inflammation triggered by cortical spreading depression and its contribution to migraine headache pathophysiology (doctoral dissertation thesis). Hacettepe University, Ankara Graduate School of Health Sciences

160. Kaya Z, Belder N, Yılmaz-Ozcan S, Donmez-Demir B, Eren-Koçak E, Karatas H et al (2019) Resolution of neuroinflammation triggered by cortical spreading 
depression. Program No. 539.09. 2019 Neuroscience Meeting Planner. Society for Neuroscience, Chicago Online. Neuroscience 2019. Chicago, IL

161. An K, Rong H, Ni H, Zhu C, Xu L, Liu Q, Chen Y, Zheng Y, Huang B, Yao M (2018) Spinal PKC activation - induced neuronal HMGB1 translocation contributes to hyperalgesia in a bone cancer pain model in rats. Exp Neurol 303:80-94. https://doi.org/10.1016/j.expneurol.2018.02.003

162. Chacur M, Milligan ED, Gazda LS, Armstrong C, Wang H, Tracey KJ, Maier SF, Watkins LR (2001) A new model of sciatic inflammatory neuritis (SIN): induction of unilateral and bilateral mechanical allodynia following acute unilateral peri-sciatic immune activation in rats. Pain. 94(3):231-244. https:// doi.org/10.1016/s0304-3959(01)00354-2

163. Tanaka J, Seki Y, Ishikura H, Tsubota M, Sekiguchi F, Yamaguchi K, Murai A, Umemura T, Kawabata A (2013) Recombinant human soluble thrombomodulin prevents peripheral HMGB1-dependent hyperalgesia in rats. Br J Pharmacol 170(6):1233-1241. https://doi.org/10.1111/bph.12396

164. Ren PC, Zhang Y, Zhang XD, An L, Lv HG, He J, Gao CJ, Sun XD (2012) High-mobility group box 1 contributes to mechanical allodynia and spinal astrocytic activation in a mouse model of type 2 diabetes. Brain Res Bull 88(4):332-337. https://doi.org/10.1016/j.brainresbull.2012.03.002

165. Nakamura Y, Morioka N, Abe H, Zhang FF, Hisaoka-Nakashima K, Liu K, Nishibori M, Nakata Y (2013) Neuropathic pain in rats with a partial sciatic nerve ligation is alleviated by intravenous injection of monoclonal antibody to high mobility group box-1. PLoS One 8(8):e73640. https://doi.org/10.13 71/journal.pone.0073640

166. Perkins ND (2012) The diverse and complex roles of NF-KB subunits in cancer. Nat Rev Cancer 12(2):121-132. https://doi.org/10.1038/nrc3204

167. Dresselhaus EC, Meffert MK (2019) Cellular specificity of NF-KB function in the nervous system. Front Immunol 10(1043). https://doi.org/10.3389/ fimmu.2019.01043

168. Zhang Q, Lenardo MJ, Baltimore D (2017) 30 years of NF-kB: a blossoming of relevance to human pathobiology. Cell. 168(1-2):37-57. https://doi.org/1 0.1016/j.cell.2016.12.012

169. Takizawa T, Shibata M, Kayama Y, Shimizu T, Toriumi H, Ebine T, Unekawa M, Koh A, Yoshimura A, Suzuki N (2017) High-mobility group box 1 is an important mediator of microglial activation induced by cortical spreading depression. J Cereb Blood Flow Metab 37(3):890-901. https://doi.org/10.11 $77 / 0271678 \times 16647398$

170. He W, Long T, Pan Q, Zhang S, Zhang Y, Zhang D, Qin G, Chen L, Zhou J (2019) Microglial NLRP3 inflammasome activation mediates IL-1 $\beta$ release and contributes to central sensitization in a recurrent nitroglycerin-induced migraine model. J Neuroinflammation 16(1):78. https://doi.org/10.1186/s12 974-019-1459-7

171. Jander S, Schroeter M, Peters O, Witte OW, Stoll G (2001) Cortical spreading depression induces proinflammatory cytokine gene expression in the rat brain. J Cereb Blood Flow Metab 21(3):218-225. https://doi.org/10.1097/ 00004647-200103000-00005

172. Grinberg YY, van Drongelen W, Kraig RP (2012) Insulin-like growth factor-1 lowers spreading depression susceptibility and reduces oxidative stress. J Neurochem 122(1):221-229. https://doi.org/10.1111/j.1471-4159.2012.07763.x

173. Grinberg YY, Dibbern ME, Levasseur VA, Kraig RP (2013) Insulin-like growth factor-1 abrogates microglial oxidative stress and TNF-a responses to spreading depression. J Neurochem 126(5):662-672. https://doi.org/10.1111/ jnc. 12267

174. Eikermann-Haerter K, Arbel-Ornath M, Yalcin N, Yu ES, Kuchibhotla KV, Yuzawa I, Hudry E, Willard CR, Climov M, Keles F, Belcher AM, Sengul B, Negro A, Rosen IA, Arreguin A, Ferrari MD, van den Maagdenberg AMJM, Bacskai BJ, Ayata C (2015) Abnormal synaptic Ca (2+) homeostasis and morphology in cortical neurons of familial hemiplegic migraine type 1 mutant mice. Ann Neurol 78(2):193-210. https://doi.org/10.1002/ana.24449

175. Gehrmann J, Mies G, Bonnekoh P, Banati R, lijima T, Kreutzberg GW, Hossmann KA (1993) Microglial reaction in the rat cerebral cortex induced by cortical spreading depression. Brain Pathol 3(1):11-17. https://doi.org/1 0.1111/j.1750-3639.1993.tb00720.x

176. Magni G, Boccazzi M, Bodini A, Abbracchio MP, van den Maagdenberg AM, Ceruti S (2019) Basal astrocyte and microglia activation in the central nervous system of familial hemiplegic migraine type I mice. Cephalalgia. 39(14):1809-1817. https://doi.org/10.1177/0333102419861710

177. Walker DG, Lue LF (2015) Immune phenotypes of microglia in human neurodegenerative disease: challenges to detecting microglial polarization in human brains. Alzheimers Res Ther 7(1):56. https://doi.org/10.1186/s131 95-015-0139-9
178. Cui Y, Takashima T, Takashima-Hirano M, Wada Y, Shukuri M, Tamura Y, Doi $\mathrm{H}$, Onoe H, Kataoka Y, Watanabe Y (2009) 11C-PK11195 PET for the in vivo evaluation of neuroinflammation in the rat brain after cortical spreading depression. J Nucl Med 50(11):1904-1911. https://doi.org/10.2967/jnumed.1 09.066498

179. Sun Y, Ma J, Li D, Li P, Zhou X, Li Y, He Z, Qin L, Liang L, Luo X (2019) Interleukin-10 inhibits interleukin-1 $\beta$ production and inflammasome activation of microglia in epileptic seizures. J Neuroinflammation 16(1):66. https://doi.org/10.1186/s12974-019-1452-1

180. Wang Z, Zhou L, An D, Xu W, Wu C, Sha S, Li Y, Zhu Y, Chen A, du Y, Chen $L$, Chen L (2019) TRPV4-induced inflammatory response is involved in neuronal death in pilocarpine model of temporal lobe epilepsy in mice. Cell Death Dis 10(6):386. https://doi.org/10.1038/s41419-019-1612-3

181. Harriott AM, Karakaya F, Ayata C (2020) Headache after ischemic stroke. A systematic review and meta-analysis. Neurology 94(1):e75-e86. https://doi. org/10.1212/wnl.0000000000008591

182. Wu LY, Ye ZN, Zhou CH, Wang CX, Xie GB, Zhang XS, Gao YY, Zhang ZH, Zhou ML, Zhuang Z, Liu JP, Hang CH, Shi JX (2017) Roles of Pannexin-1 channels in inflammatory response through the TLRs/NF-kappa B signaling pathway following experimental subarachnoid hemorrhage in rats. Front Mol Neurosci 10:175. https://doi.org/10.3389/fnmol.2017.00175

\section{Publisher's Note}

Springer Nature remains neutral with regard to jurisdictional claims in published maps and institutional affiliations.

\section{Ready to submit your research? Choose BMC and benefit from:}

- fast, convenient online submission

- thorough peer review by experienced researchers in your field

- rapid publication on acceptance

- support for research data, including large and complex data types

- gold Open Access which fosters wider collaboration and increased citations

- maximum visibility for your research: over $100 \mathrm{M}$ website views per year

At BMC, research is always in progress.

Learn more biomedcentral.com/submissions 